\title{
Using Informal Institutions to Address Resettlement Issues - The Case of Ghana Dams Dialogue
}

\author{
Richard Twum Barimah Koranteng ${ }^{1,2}$ \& Guoqing Shi ${ }^{2}$ \\ ${ }^{1}$ Volta Basin Development Foundation, Ghana \\ ${ }^{2}$ National Research Centre for Resettlement, Hohai University, China \\ Correspondence: Richard Twum Barimah Koranteng, Hohai University, 8 Focheng West Road, Jiangning \\ District 211100, Nanjing, Jiangsu, China. Tel: 86-150-6224-9514. E-mail: rtwumus@yahoo.com
}

Received: March 14, 2018

doi:10.5539/jsd.v11n4p27
Accepted: May 21, 2018 Online Published: July 29, 2018

URL: https://doi.org/10.5539/jsd.v11n4p27

\begin{abstract}
The study set off to address resettlement issues through the effective utilization of informal institutions, vis-à-vis the Ghana Dams Dialogue, but specifically sourced information from respondents inhabiting both Kpong and VRA resettlement townships (KAVRTs) in Ghana. Among other objectives, the study investigated the key economic and social implications of resettlement schemes on displaced individuals, in addition to the critical factors affecting informal institutions in addressing resettlement issues in Ghana. Per the study's execution, the researcher adopted both qualitative and quantitative method of research as well as convenience sampling technique to select respondents at the institution for their views on the study. A questionnaire was adopted as the main survey instrument while 5-Point Likert scale which was later transform into the Relative Importance Index (RII) was employed to facilitate the analysis of data obtained from the field. Findings of the study indicated the 6 key economic and social implications of resettlement schemes on displaced individuals' determinants at KAVRTs as high morbidity/mortality rates, loss of economic power, compromising and destroying of farming systems, livelihood deficits and marginalization, psychological and socio-cultural stress as well as disorganization and framework of indigenous markets dissimilar from the erstwhile format. Furthermore, with respect to the critical factors affecting informal institutions in addressing resettlement issues at KAVRTs, 6 notable constructs were also intimated by the respondents', namely: in effective planning regimes, restrictive implications of livelihood restoration programs, procedural delays associated with compensation, lack of transparency in land allocation/farming techniques and partiality, inadequate compensation and rehabilitation assistance in addition to questionable housing policy. Having noted the critical factors informal institutions face in addressing resettlement issues at KAVRTs, the study recommended it strictly adheres to the promotion of interactions among stakeholders on compensation issues, swift maturation of GDD policy levels, GDD strengthening of its engagement with relevant agencies, effective participation, upholding of citizenship rights, identification and evaluation of asset contribution, provision of social amenities, active NGO participation, promotion of shared cultural values, vis-a-vis livelihood support programs (LSP) among others captured in the study to manage the critical issues raised.
\end{abstract}

Keywords: informal institutions, resettlement issues, Dams, dialogue, Ghana

\section{Introduction}

\subsection{Background of the Study}

For the past few decades, the world has witnessed an unprecedented surge in urbanization, making it possible for the terminology "urbanization" to gain immense prominence within the academia, private, public sector organizations vis-à-vis not-for-profit and corporate entities in Ghana and beyond including World Bank and United Nations (UN-Habitat, 2008). According to UN-Habitat (2008), with an estimated population of approximately five billion individuals inhabiting most parts of the urban localities across the globe, specifically in developing economies (UN-Habitat 2008), it is eminent that government and key stakeholders at all strategic and tactical levels provide basic infrastructural support and social services to promote the wellbeing of its citizenry as postulated by Adu-Gyamfi (2012).

Furthermore, before time immemorial, indigenous communities have been bedeviled with the repercussions of 
the infrastructural advancement institutionalization like, agric-oriented projects, as well as the expansion of city and urban expansion with national parks inclusive. Albeit, these development-oriented projects are touted to be of national relevance, they have been going neck and neck with indigenes for land, vis-à-vis its land affiliated resources' accessibility. These projects that are development-oriented have subjugated local communities and subsequently relegated them to the background as regards primordial localities and relocating or pressurizing them to fish out for substitute land in peripheral frontiers (De Wet, 2006). Advancement projects necessitating existing engaged land consist of diversified threshold of resettlement obtained in a forceful manner (Woube, 2005; Cernea, 2004). Infrastructural projects with advancement orientation, in addition to development programmes appears to be one of the notable origins of enigma that pertains to the environment, which more often than not triggers social unrest perilous scenarios. A hypothetical scenario to buttress this point pertains to one glaring South American economy, Brazil, where community revolutionaries propounded the regional commission to oppose mega dams, which served as a proof to individual troubled by expatriation (Cernea \& Guggenheim, 1993).

Quite a sizable number of pledges and statutory frameworks have been developed and effectuated to safeguard advancement-enhanced deranged individuals. These frameworks are made available by international civil liberty statues (ICLSs) and privileges under the household juridical system if the country is an endorser to the ICLS. In view of this, anytime the state compromises with its protection enforcement regimes, it signifies that the government is not on top of its brief as far as the protection of the subjugated folks is concerned. This scenario rears its ugly head in view of the fact that the enforced re-locators are generally confined to their country of origin. Hence, governments across the globe should do all they can to guarantee re-locators absolute protection within any stipulated time period. Lund (2009), as matter of urgency, advocates for a thin line to be drawn between the refugee system and displacement scenarios, specifically when the dislocation is triggered by advancement projects like dams' construction just to mention a few (De Wet, 2006).

According to Lund (2009), dam projects have deranged individual since the nineteen fifties by remodeling after World War II in developed economies. Synonymously, contemporary independent economies like Ghana had its fair share of advancement-affiliated derangement. Albeit, during the last twenty years, the degree of pressurized derangements necessitated by advancement project soared to ten thousand folks annually or some 200,000,000 individuals worldwide (Cernea, 2004). Re-location ground rules and derangement stratagems in myriads of economies, states and multinational companies (MNCs), have been propounded, thereby boosting pressurized deranged aftermaths such as the construction of dams in China (De Wet, 2006).

From the global perspective, China tops the list as far as the optimum portion of advancement-enhanced derangement is concerned. For instance, the 3 Gorges Dam happens to be the bulkiest HP project. It is normally postulated that the project in contention deranged more than one-million and two hundred thousand 1,200,000 folks from thirteen cities, one hundred and forty towns, as well as one thousand, three hundred and fifty villages. Furthermore, the reservoir's reach spans above six hundred kilometres. That notwithstanding, some schools of thought argue that the project was bedeviled by malfeasance, civil liberties' compromises, enigma relating to the environment just to mention a few difficulties (International Rivers, 2011). In Africa, DED have influenced meagre-populated frontiers than those tilted towards Asia. However, DED affect huge land localities in Africa as compared to its Asian counterparts or terrains. From the Ghanaian perspective, the Akosombo dam inundated about three point five percent of Ghana's land mass in totality (Lund, 2009). A computed summation of individuals deranged by dam projects with Bui dam inclusive in Ghana is approximately hundred million, two hundred and sixteen thousand.

More so, Cernea (1997) submits that energy pundits who are also strong advocates of sustainable development have emphatically stressed that the period spanning between 1990 and 2020 will epitomize a 30-year era of unprecedented growth surge in energy demand and supply in the developing economies with the proliferation of dam construction likely to continue in a sustained dimension. Put simply, these so-called energy gurus are of the strongest conviction that dams provide infrastructural element necessitated for national development. Conversely, some schools of thought have argued that the magnitude of negative repercussions associated with dam is justifiable to prevent its construction (Cernea, 1997). Strictly speaking, dam construction devoid of effective resettlement schemes for the masses displaced in those localities more often than not, culminate into extremely debilitating consequences and retrogressive tendencies (UNHCR, 2011; Yen, 2003). Furthermore, it promotes land degradation, ravages territory and cultural assets, and serves as encumbrance to the myriads of the teeming arrangement of organizational settings within our society vis-à-vis sovereignty development via crucial environmental consequences (Woube, 2005; Asante-Manteau, 2011). To add to this, past development projects that have involved pressurized resettlement have showed instances of underestimation, miscalculation, and 
undervaluation of compensation which resort affected persons to struggle and find other alternative in order to make a living (RDI, 2007; Zaman, 2010; Scudder, 2005).

From the Ghanaian perspective, the implementation, planning and management of compulsory acquisition have also been occupied with underestimation and undervaluation of compensation packages mainly because the processes and standards for undertaking land acquisition activities have been undermined (Larbi, 2008), as a result even after a period of forty five years that compulsory acquisition involving involuntary resettlement began, there are still some challenges between displaced persons, host communities and implementing organizations unresolved (Raschid-Sally et al. 2008). These encumbrances ranges from dilapidated and lack of infrastructural facilities, huge outstanding compensation, tenure security deficits, joblessness, monetary hardship, accessibility to investment and credit opportunities inadequacies, rural-urban migration, conflict over community resources and quarrels over community leadership (Raschid-Sally, Akoto-Danso, Kalitsi, Ofori \& Koranteng, 2008). Particularly, these involuntary resettlement failures have occurred as a result of lack of funding, weak administrative and legal framework, political restructuring and land tenure arrangements (Gordon, 2006). These challenges have different manifestation on the lives of project affected people as it hinders the socio-economic development.

In view of the above-mentioned setbacks bedevilling countless number of resettlement schemes across the country, the government has as a matter of exigency, embraced myriads of mitigating strategies like environmental readiness, social and environmental impact assessment, action plans geared towards resettlement regimes, heavy reliance on informal institutions in tandem with Ghana Dams Dialogue (GDD) just to mention a few. Irrespective of the myriads of strategic intervention mechanisms and positive strides embarked upon by previous governments, civil society organisations (CSOs), resettlement-oriented researchers in addition to not-for-profit entities to curtail the bottlenecks associated with resettlement schemes, the enigma continues to still linger on within the Ghanaian jurisdiction.

It is against these backdrops that the researcher seeks to investigate the key economic and social implications of resettlement schemes on displaced individuals, determine the critical factors affecting informal institutions in addressing resettlement issues in Ghana and subsequently proffer remedies to manage the issues identified during the study.

\subsection{Problem Statement}

According to Kyei-Dompreh (2012), land acquisition for mega projects like the construction of dams have always been an intriguing enigma to quite a sizable number of individuals, agencies and organizational settings across the globe. Simply put, debilitating issues have often been managed in a lackadaisical and superficial fashion. The non-existence of clearly defined objectives and roles, consistent procedures and sufficient accoutrements for providing long lasting panaceas to resettlement excesses had culminated into serious negative consequences on the individuals displaced, among others.

Ghana's historical perspective encompassing the construction of dams for irrigation and HEP purposes could be traced to the early parts of the 60 's with myriads of them being built for irrigation and electricity purposes. That notwithstanding, it was not until Akosombo Dam construction on the Volta River that the issues around re-location cropped up. Strictly speaking, the dam required resettlement of eighty thousand inhabitants but as of today, after about half of century of its construction, there appears to be a deficit with respect to its absolute settlement of the enigmas which has jeopardized the project's continuity as opined by Raschid-Sally, Akoto-Danso, Kalitsi, Ofori and Koranteng in (2008).

With particular reference to the experience emanating from the Akosombo resettlement project and the like, it is anticipated that strategic remedies are put in place by the government to provide a replacements for the displaced folks, vis-à-vis ensuring a sustained connection between the generations pertaining to the families (Sutcliffe, 2009; Mettle, 2011). This would inadvertently go a long way in curtailing encumbrances underpinning the incessant social, cultural, in addition to the economic perspectives of the victims' lives in addition to the persistent and potential environmental challenges.

Previous research works that accentuates on addressing resettlement issues through the effective utilization of informal institutions in Ghana, specifically using both Kpong and VRA resettlement townships appears to be non-existent, unexploited and under-researched. Strictly speaking, research works that seeks to investigate the key economic and social implications of resettlement schemes on displaced individuals in addition to determining the critical factors affecting informal institutions in addressing resettlement in Ghana, with a heavy reliance on the above-mentioned localities seem to be a mirage and far-fetched. 
Furthermore, from a critical appraisal of related literature suggest quite a sizable plethora of extensive research projects embarked upon that relates to resettlements in Ghana and the world in its entirety but absolutely not the topic under scrutiny. However, the researcher's chosen topic is yet to be extensively subjected to any rigorous empirical assessment especially in many developing countries including Ghana (a void or research gap that needs to be filled).

This study therefore seeks to trigger the platform for more scientific research endeavors, academic discussion and consequently abridge this research vacuity by investigating the key economic and social implications of resettlement schemes on displaced individuals, determine the critical factors affecting informal institutions in addressing resettlement issues in Ghana and inadvertently propose strategic initiatives deemed fit to manage the afore-mentioned issues with a heavy reliance on both Kpong and VRA resettlement townships.

\subsection{Aim and Objectives of the Study}

The pivotal objective of this study is to address resettlement issues through the effective utilization of informal institutions in Ghana through a survey. The specific objective are:

1) To investigate the key economic and social implications of resettlement schemes on displaced individuals in Ghana.

2) To determine the critical factors affecting informal institutions in addressing resettlement issues in Ghana.

3) To propose strategic intervention mechanisms to effectively manage the critical factors affecting informal institutions in addressing resettlement issues in Ghana.

\subsection{Research Questions}

In consonance with the problem statement, the study leaves no stone unturned to give precedence to the under-listed research questions:

1) What are the key economic and social implications of resettlement schemes on displaced individuals in Ghana?

2) What are the critical factors affecting informal institutions in addressing resettlement issues in Ghana?

3) What strategic intervention mechanisms should be employed to effectively manage the critical factors affecting informal institutions in addressing resettlement issues in Ghana?

\subsection{Significance of the Study}

Resettlements and its associated socio-economic pitfalls are indispensable precursors of sustainability of countless number of developmental projects worldwide. The main rationale of resettlement schemes is to provide an impetus for beneficiaries so as to enable them live to maintain an appreciable standard of living after the implementation of the project (WCD, 2000). It is worth noting that the inhabitants mostly affected in any resettlement scheme largely fall within the poverty bracket.

In view of this, it is expected that any developmental intervention mechanisms does not exacerbate the situation in the foreseeable future (Sutcliffe, 2009). These so-called debilitating conditions ought to be reversed so as to boost the sustainability of any resettlement regime in Ghana and beyond. There is therefore the exigent need to evaluate resettlement project sustainability in order to create awareness for policy makers with respect to developmental gaps and excesses that need the requisite precedence and live up to its successful billing

Lastly, the research would invariably provide ground rules (codes) and policy tutoring for the government and the like to seriously accord the necessary recognition to cultural and socio-economic committals of the indigenes via incessant environmental constraints within the locality and ensure that further developmental schemes endure the testing times as and when due.

\subsection{Scope and Limitations of the Study}

This study is addressing resettlement issues with particular emphasis on informal institutions in Ghana, specifically using Kpong and VRA resettlement townships as case study localities vis-à-vis the Ghana Dams Dialogue (GDD) as a reference point. Thus, skewing the case study to only the afore-mentioned localities and GDD may not connote the generalizability with respect to the topic under scrutiny from the Ghanaian perspective. Albeit, the procedure makes clear and gives us sufficient dominance over the parameters (changeables) vis-à-vis the data required to be examined in the study. The propensity of respondents providing unreliable information that could distort the outcomes of the research is another bone of contention that cannot be overemphasized. 


\subsection{Organization of the Study}

The research report is organized into five chapters. Chapter one gives introduction and general background of study, problems statement, aims and objectives of the study including significance of the study among others. Chapter two reviews relevant literature (theoretical and empirical) on the research area describing contemporary and past trends that pertains to resettlements and its associated domains in Ghana and beyond. Chapter three describes the sources of data and techniques used in data collection. Chapter four focusses on discussion and analysis of the results. Summary, conclusion and recommendations of the study are given the requisite precedence in chapter five.

\section{Literature Review}

\subsection{Overview}

This segment underpins and accentuates on the theoretical and empirical research works of countless number of essayists that pertains to resettlements across the nooks and crannies of the globe.

\subsection{Concept and Meaning of Displacement}

The World Commission on Dams (WCD) in 2000, defined the term "Displacement" as an unplanned adverse periphery relating to projects that developmental-oriented. Derangement brought about by projects that are development-oriented happens to be sole astronomic predictor of unintentional movement across the rank and file of the globe (Oliver-Smith, 2002; de Wet, 2006; Pankhurst \& Piguet, 2009). To add to this, derangement is perceived to be the effect brought about a development model that commandeers certain technically-motivated, in addition to monetary preferences devoid of any crucial deliberation to alternatives that would constitute the trivial relating to the society, and the environment as a whole (Bartolome, De Wet, Mander \& Nagraj, 2000; Munshifwa, 2007).

Collectively, projects that are development-affiliated other than hostility gives rise to unprecedented and mammoth population of human movements from one geographical frontier to the other (Robinson, 2003). Such projects displace approximately $15,000,000$ individuals annually (Cernea, 2008). Infrastructural development spanning between 1990 and 2000 caused the displacement of ninety to hundred million folks (Cernea \& McDowell, 2000). This translates to $10,000,000$ individuals annually who were deranged by substratum advancement projects globally (Cernea, 2000; Hordofa, 2003). The critical enigma regarding derangement as of today was necessitated by the construction of dam which was associated with the displacement of forty to eighty million folks (Cernea, 2000; WCD, 2000).

\subsection{The Concept and Meaning of Resettlement}

The terminology "resettlement" is credited with diverse delineations and has in effect made it extremely arduous for essayist across the globe to stamp their authority as far as giving an exhaustive connotation to the concept. Quite a sizable plethora of essayists have tried to give an explanation to the concept in contention. Woldeselassie, (2002) delineates resettlement as the migration of populace from one geographical precinct to another frontier, in addition to the alteration of the tangible and civil milieu in which the individuals inhabits and get acclimatized, and also proceeded to further expansiate on the abstraction as a mixture of movement categories. This may be the reason why some school of thought refer to the concept in other terminologies like "enforced movement (EM)", "transplanted folks (TF)", "deranged individuals (DIs) just to mention a few (Phonepraseuth, 2012).

Based on the afore-mentioned definitions, the researcher defines the term "resettlement" as a migration of humans from one locality to the other be it voluntary or involuntary. To buttress this point, two dissimilar domains surfaces in the myriads of definitions, i.e. to say, resettlement could be tagged as "voluntary" or willingness by individuals as a result of the developmental projects' repercussion and involuntary if the folks are ejected forcefully. That notwithstanding, although sustainability deficits appear to be left out in the delineations presented, embedded in them is the concept that individuals who are hurt emotionally by relocation, ought to fix their previous lives whiles in their contemporary abode localities, be economically and socially empowered, vis-à-vis ensuring the sustainability of the resettlement scheme.

\subsection{Economic and Social Implications of Resettlement Schemes on Individuals}

A tentative review of previous and past researches proffers two prominent implications of expatriation courses of action relating to developing economies which are carefully distincted into affirmative and adverse ramifications. For instance, Brightmer (1983) submitted that, with the exception of few derangement ramifications; favourable alterations that pertains to the society, fiscal and tangible edifices, in addition to earnings and scenery advancement. Alterations of that nature per the submission of Brightmer (1983) epitomize the heightening of 
neighbourhoods, enhanced population, vis-à-vis the construction of federal institutional settings, augmented living standards, just to mention a few. Furthermore, Olawepo (1997) opined that the Kainji resettlement scheme was undoubtedly one of the indispensable and prominent inroads that was associated with developing countries in Sub Sahara Africa because it invariably transformed the living standards of those displaced as compared to their previous resettlement precincts. He proceeded to postulate that the expatriation led to the emergence of infrastructural edifices within the society, re-establishment proliferation, as well as fraternization.

Some schools of thought posited that irrespective of the advantageous implications of resettlement, its associated repercussions cannot be relegated to the background. Cernea and McDowell (2000b) found out that resettlement more often than not culminates into livelihood deficits in addition to depreciation in income sources like arable lands suitable for agricultural productivity among others. They further argued that the monetary (fiscal) effectiveness depreciation, coupled with the disintegration of sophisticated sustenance processes results in short-lived or perpetual, which more often than cannot be reversed, falling living standards of the individual culminating into suppression (subjugation). More so, Kalin (2000), submits that involuntary resettlement should be considered a nip in the bud as and when due through the exploration of all feasible likely undertaking work blueprints. This presupposes that the consequential implications of expatriation are so intense (vivid) that the re-locators find it extremely laborious to return to normalcy. Again, Mulugeta et al., (2011) contend that expatriation occurrence is more often than not fraught with unproductiveness, inoperative, disastrous, melancholic, and circumstantially pestilential to the individuals associated with the happenings. Pankhurst and Piguet (2009), propounded a social perspective to the implications of expatriation and came to a candid opinion that it translates into the disappearance of individuals' sustenance and sources of earnings like lands suitable for agric productivity just to mention a few.

More so, the extensive research projects effectuated by the likes of Mengistu (2005), Gebre (2009) and Wolde-Selassie (2009) hugely connote the complete debacle, servitude life happenings of re-locators affiliated to Ethiopia spanning the past few decades. As per the argument of Cernea (2000), research projects affiliated to sociology has enormously exposed the cognitive stress, optimal death rate that pertains to involuntary resettlement. As intimated by Cernea (2000), the aftermath of forced expatriation in countless economies across the globe encompasses the destruction of farmlands, disintegration of social support network which invariably culminates into impoverishment of countless number of small and medium households (family relations). In conclusion, Cernea (2000) postulated seven risks associated with deranged folks. The afore-mentioned risks are touched on briefly in the next subsection:

Land deficiency: The issues encompassing land deficiency may represent the form of partially or wholly deprivation of erstwhile inhabited land, as well as inaccessibility to resources that pertains to common property. The repercussion associated with inaccessibility to resources that communities are heavily dependent on happens to be a depreciation in the monetary effectiveness of communities in a holistic manner, coupled with adverse social alterations (Cernea, 1996; Magembe-Mushi \& Lupala, 2015).

Absence of jobs: As opined by Cernea (1996), in consonance with Magembe-Mushi et al., (2015), joblessness is prevalent in rural settings, in addition to the urban populace. From the rural frontier perspective, job non-existence or partial employment is mainly the aftermath land loss, whereas in the urban environs, deranged folks experience intense arduousness as far as jobs' searching is concerned (Magembe-Mushi et al., 2015).

Home deficits: Per the assertion of Magembe-Mushi et al., (2015), types of derangement are associated with perpetual accommodation deprivation. In most scenarios, it might connote incessant vagrancy or vagabondage adversely impacting on a household (absolute family relation) (Magembe-Mushi et al., 2015).

Subjugation (marginalization): Fernandes, Nafisa, Arundhuti and Mohammed (2001), as well as Magembe-Mushi et al., (2015) postulated notable divisions of marginalization bedeviling deranged folks. The segments are as follows: communal (civil), monetary, and cognitive. Monetary subjugation is mainly brought about by sluggish or abrupt derangement of those in a contemporarily minimal monetary threshold. A hypothetical case to their argument relates to the monetary subjugation of peasant farmers.

Enhanced morbidity rates: Health hazards associated with deranged folks are undoubtedly, the repercussion of dietary deficiency, sanitation inadequacies, as well as water supply deficits. Sanitation lapses may trigger the spread of communicable maladies like dysentery just to mention a few (Oucho \& Rodgers, 2005).

Non-existence of food security: Depreciation in human safeguarding threshold triggered by derangement may connote a short-lived or perpetual enigma. More often than not, it is a result of land deficits and insufficient accessibility to ordinary (informal) natural resources. Interestingly, women and young children are glaring victims in this perspective (Oucho et al., 2005). 
Inaccessibility to non-rare resources: The effective utilization of indigenous communal resources is indispensable as far as the monetary schemes for the myriads of local populace is concerned. The resources in contention titivate individuals to effectuate countless number of their monetary operations on a daily basis including firewood gathering, food, and fishing among others (Cernea, 1996).

It is worth noting that these repercussions are indispensable as far as the assessment of the sustainability like Bui Dam. This can be attributed to the fact in the event that they do occur and are not properly managed, it could prompt displaced individuals to relocate and further culminate into abject poverty, health, socio-economic and environmental consequences (Miine, 2014).

The table 1 below accentuates on economic and social implications of dam construction and operations in Africa.

Table 1. Hypothetical scenarios relating to the economic and social implications of dam construction and operations (Africa)

\begin{tabular}{|c|c|}
\hline Locality & Implications \\
\hline $\begin{array}{ll}\text { Kafue } & \text { flats } \\
\text { (Zambia) } & \end{array}$ & $\begin{array}{l}\text { The building of the Itezhi-Tezhi dam has given rise to: (a) Loss of traditional flood recession garden } \\
\text { systems; (b) Decreased in grazing resources stemming from vegetation on the floodplain and } \\
\text { augmented dry season inundation; (c) Fish species alterations and an upsurge in catch effort as a } \\
\text { result of larger localities of dry season open water (Acreman, Farquharson, Mc Cartney, Sullivan, } \\
\text { Campbell, Hodgson, Morton, Smith, Birley, Knott, Wingfield \& Barbier, 2000). }\end{array}$ \\
\hline
\end{tabular}

\begin{tabular}{lll}
\hline $\begin{array}{l}\text { Senegal } \\
\text { (Senegal) }\end{array}$ & Delta & $\begin{array}{l}\text { The construction on the Diama dam has culminated into: (a) Breakdown of livelihoods reliant on } \\
\text { fisheries; (b) Livestock grazing through reduced flood dependent pasture losses; and (c) Vegetation } \\
\text { losses used for mat making (erstwhile), etc. (Duvail \& Hamerlynck, 2003). }\end{array}$ \\
\hline $\begin{array}{l}\text { Tana } \\
\text { (Kenya) }\end{array}$ & River & $\begin{array}{l}\text { The construction on the Tana River have resulted in (Mc Cartney et al., 2010): (a) Decline in } \\
\text { riverine pasture; (b) Increased pressure on common pool resources shared by farmers and } \\
\text { pastoralists; (c) Acceptance and increased reliance of local people on state authority which is } \\
\text { rendering tribal and inheritance-based customary systems of regulated access to floodplain farm and } \\
\text { grazing resources increasingly becoming redundant. }\end{array}$ \\
\hline $\begin{array}{l}\text { Atbara } \\
\text { (Sudan) }\end{array}$ & River & $\begin{array}{l}\text { The construction on the Atbara River in Sudan have resulted in (Abdel-Ati, 1992): (a) Dereliction of } \\
\text { traditional irrigation methods and increased share-cropping arrangements between farmers and } \\
\text { diesel pump owners; (b) Decline in households involved in agriculture from 92\% to } 81 \% \text { between } \\
\text { 1964 and 1989; (c) Disappearance of fishing and wood collection as livelihood strategies; and (d) } \\
\text { Enhanced out-migration as result of the reduction in cultivable land. }\end{array}$ \\
\hline
\end{tabular}

Hadejia-Jama.are Reduction of flooding in the Hadejia-Nguru wetlands due to upstream dam construction, has Rivers (Nigeria) resulted in (Barbier et al., 1993): (a) Reduction in agriculture (e.g. rice); (b) Loss of grazing resources (mainly cattle of the Fulani people), decrease in non-timber forest products, fuel wood and fishing for local populations; (c) Reduction in the economic value of production in the wetlands, which analysis indicates is by far greater than that derived from the irrigation schemes for which the river has been dammed.

\begin{tabular}{|c|c|}
\hline $\begin{array}{l}\text { Volta } \\
\text { (Ghana) }\end{array}$ & $\begin{array}{l}\text { Construction of the Akosombo dam in Ghana resulted in (Gyau-Boakye, 2001): (a) Increased } \\
\text { incidence of myriads of water borne diseases including schistosomiasis, malaria and onchocerciasis, } \\
\text { in lakeside villages and dam's downstream; (b) Increased salinity in water supply for some towns, } \\
\text { downstream of the dam; (c) Decline in economic activities as a result of agricultural land loss; (d) } \\
\text { Breakdown in traditional social order, in part due to the loss of ancient sacred places. }\end{array}$ \\
\hline $\begin{array}{l}\text { Logone } \\
\text { Floodplain } \\
\text { (Cameroon) }\end{array}$ & $\begin{array}{l}\text { Construction of the Maga dam in Cameroon resulted in (Mouafo et al., 2002): (a) Growing disputes } \\
\text { between various interest groups relating to water accessibility; (b) Collapse of fisheries due to loss } \\
\text { of floodplain habitat; (c) Soils and pasture degradation due to lack of silt inputs to the floodplain; (d) } \\
40 \% \text { reduction in population of the floodplain due to the migration of individuals. }\end{array}$ \\
\hline
\end{tabular}

Source: McCartney, Awulachew, Seleshi, Prasad, Tarekegn \& King (2005)

ADB (2010) and World Bank (2002) provides a detailed resettlement planning process that pertains to the teeming developmental projects worldwide (see table 2 below): 
Table 2. ADB resettlement planning process

\begin{tabular}{lrl}
\hline \multicolumn{1}{c}{ Topic } & & \multicolumn{1}{c}{ Contents } \\
\hline $\begin{array}{l}\text { Scope of } \\
\text { acquisition } \\
\text { resettlement }\end{array}$ & $\begin{array}{r}\text { land } \\
\text { and }\end{array}$ & $\begin{array}{l}\text { Provide a cartographical description, land acquisition scope and the reason why it is expedient for } \\
\text { primary project with an investment focus. Description of likely preferences, if any, taking } \\
\text { cognizance of land acquisition reduction and its associated implications, and why the left over } \\
\text { repercussions are inevitable. Abridging pivotal implications regarding purchased lands, } \\
\text { disappearance of assets, and individuals deranged from their abodes or sustenance. Hitting the nail } \\
\text { on the head as regards instrumental tenets for acquiring land, in addition to expatriation. }\end{array}$
\end{tabular}

Socio-economic information
Delineate, fish out and count individuals to be deranged. Delineate probable implications of land acquisition on individuals deranged, taking cognizance of socio-cultural, and monetary attributes. Unearth all losses pertaining to folks troubled by the acquisition of land. Show any ordinary asset resources' details. Accentuate on how project will influence on the deprived and poverty-stricken individuals, ethnic small groups, and other susceptible groups, as well as women, and any unique initiatives required to concretize completely, or enhance, their monetary and civil perspective.

\begin{tabular}{lrl}
\hline Objectives, & policy & Delineate aim and objectives of land purchasing and expatriation. Delineate pivotal national and \\
framework, & and & $\begin{array}{l}\text { local land, indemnity and resettlement policies, laws, and guidelines that apply to project. Throw } \\
\text { entitlements }\end{array}$ \\
& $\begin{array}{l}\text { more light on how Financial Institution's Code on Forced Expatriation will be attained. Spell out } \\
\text { principles, judicial and code commitments from borrower executing agency for diversified } \\
\text { divisions of project implications. Construct an eligibility code and claim patterns for all loss types, } \\
\text { in addition to indemnity rates. }\end{array}$
\end{tabular}

$\begin{aligned} & \text { Consultation, } \\ & \text { grievance } \\ & \text { participationd }\end{aligned}$
redress

Relocation of housing and settlements

Fish out project collaborators. Delineate strategies for collaborators involvement in planning, management, monitoring, and evaluation. Unearth indigenous institutional settings or organizational framework to assist individuals troubled by derangement. Re-assessment of pivotal role of nongovernment organizations and community-based organizations. Come out with guidelines for redress of grievances by individuals deranged.

Fish out for alternatives that pertains to housing relocation, vis-à-vis other structural edifices, as well as housing and cash compensation replenishment, among others. Spell out initiatives to assist with the resettlement processes at new localities. Appraise alternatives for developing relocation sites, if required, in terms of locality, site quality, and developmental needs. Provision of a plan for layout, design, and civil infrastructure for each locality. Spell out modes for protecting earnings and sustenance. Spell out measures for planned integration with host communities. Identify special measures for addressing gender issues and those related to vulnerable groups. Identify any environmental risks and show how these will be managed and monitored.

Income rearth sustenance at risk. Construct an earning reformation (remodeling) initiative with
(1) privileges in a job construction scheme, as well as the provisions for earning replacements, re-coaching, entrepreneurship and pensions, where applicable. Development of a scheme to resettle and make new businesses, including earning replacement where applicable. Fish out any environmental hazards and spell out how these will be controlled and supervised.

\section{Institutional} framework

Unearth main duties and roles in planning, negotiating, consulting, approving, coordinating, implementing, financing, monitoring and evaluating land acquisition and resettlement. Appraise the land acquisition authority and expatriation outfits and their ability to control and manage these duties. Make room for capacity building, including technical assistance, if applicable. Spell out NGOs' responsibilities, if applicable, and organizations of APs in expatriation planning and management.

\begin{tabular}{|c|c|}
\hline $\begin{array}{l}\text { Resettlement budget } \\
\text { and financing }\end{array}$ & $\begin{array}{l}\text { Unearth acquisition and resettlement costs relating to lands. Come out with a yearly budget and } \\
\text { spell out the timing for funds' release. Spell out funding sources as well as all land purchasing and } \\
\text { expatriation operations. }\end{array}$ \\
\hline $\begin{array}{l}\text { Implementation } \\
\text { schedule }\end{array}$ & $\begin{array}{l}\text { Make provision for a timetable schedule depicting commencement and completion dates for } \\
\text { striking expatriation roles. Illustrate how individual troubled as a result of derangement will be } \\
\text { made available before destruction kickstarts. }\end{array}$ \\
\hline $\begin{array}{l}\text { Monitoring } \\
\text { evaluation }\end{array}$ & $\begin{array}{l}\text { Develop a scheme for intrinsic monitoring of expatriation targets, pin pointing essential } \\
\text { development predictors, mechanisms for reporting, and resource requirements. Prepare an } \\
\text { evaluation plan, with provision made for the exterior, independent assessment of the magnitude to } \\
\text { which code objectives have been attained. Spell out involvement for individual troubled in } \\
\text { monitoring and evaluation. }\end{array}$ \\
\hline
\end{tabular}

Source: ADB (2010) 
The International Finance Corporation handbook for preparing a Resettlement Action Plan also recommends the following process involved in resettling people. These are:

- Project impacts and APs identification;

- Land acquisition and compensation legal framework;

- Framework relating to compensation;

- Resettlement assistance and restoration of livelihood activities description;

○ Comprehensive budget;

- Schedule with respect to implementation;

- Organizational responsibility's description;

- Public consultation, participation, and development planning framework;

○ Provisions for redress of grievances description; via

○ Monitoring, evaluation, and reporting frameworks.

Pertaining to the RPP, it can be deduced that the unflinching effort emanating from the myriads of collaborators cannot be overemphasized. One notable parameter feature which is prevalent within the RPP stems from the propensity to regularly supervise the RPP so as to ensure that they live up to their billing as far as the attainment of their set objectives is concerned. Any attempt to side-line the RPP may culminate into derangement debacle in the final analysis (Miine, 2014).

\subsection{Factors Influencing Informal Institutions in Mitigating Resettlement Challenges}

This section encompasses the factors influencing informal institutions in mitigating resettlement challenges:

\subsubsection{Questionable Housing Policy}

The housing policy that was adopted in the Akosombo resettlement regime was the Do-It-Yourself (DIY) labour strategy involving one thousand three hundred housing units erected by the land claimers, were supposed to be finished-off by the displaced indigenes. The completion of the core houses required skills and techniques, hence, affected people (AP) were provided with technical assistance as well as building materials in addition to uniform standard housing designs. The initial single room core houses that were provided for the resettlement communities could not accommodate individual families due to exorbitant family capacity (number of family members). That is to say, no contingency plan was factored into the family capacity. During the execution of Akosombo resettlement project, there were non-existence of property valuation specifications to determine appropriate compensation to reinstate affected properties. This debilitating condition prompted resettlement authorities to adopt a standardized housing scheme to be distributed indiscriminately to affected households. It is sad to note that, some of the core houses that were provided by the then government to replace affected people still remain intact (dilapidated and deplorable housing units) (Gordon, 2006).In view of the fact that resettlement localities should be equipped with critical infrastructural accoutrements like quality water supply, effective transportation mechanisms and modes via effective communication linkages, Akosombo resettlement localities were bedeviled with the contrary. This invariably triggered the teeming youth to relocate to more attractive urban precincts among others in dire need for improved standards of living and its associated attractive and mouth-watering goodies (De Wet, 2006).

\subsubsection{Ineffective Planning Regimes}

Contemporarily, effective planning regime is indispensable as far as achieving a superior quality and zero defect resettlement scheme across the globe is concerned. Strictly speaking, planning excesses that emanated from the Bui dam construction triggered transparency and fairness deficits with respect to the distribution of housing units within the resettlement communities. For instance, as a result of time overruns encountered by those at the helm of affairs (dam construction), AP who settled at Jama community were initially informed of their inability to use the locality as permanent place of residence. However, that decision was reversed somewhere along the line.

Furthermore, during the relocation era, four separate communities were put together at Jama township without taking cognizance of their religious affiliations, socio-demographic attributes just to mention a few. In effect, each religious group upon arrival requested for a separate place of worship. However, the financial incapacitation the authorities were saddled with prompted them to erect one community centre for all the teeming members to be used as a place of worship and other social programs. This latest development did not augur well with the indigenes in the long run (Mettle, 2011; Yen, 2003). 


\subsubsection{Lack of Transparency and Fairness in Land Allocation and Farming Techniques}

One of the most common resettlement policy prevalent in Ghana relates to land allocation and farming technique. Primarily, this strategy is mostly opted for in view of the fact quite a sizable plethora of AP's are predominantly farmers (heavily dependent on agriculture as their source of livelihood). For instance, pertaining to the Akosombo resettlement scheme, the main livelihood restoration program employed for the AP was four hundred and thirty thousand acres of sophisticated and state-of-the-art agriculture which relied on communal-related technique. This program was said to have been altered into traditional method of farming practices whereby each household were given three acres of land (Kalitsi, 2008).

The four hundred and thirty thousand acres agriculture initiative in Akosombo resettlement failed during its testing stage as a result of inability by project authorities to clear land for farming, delay in getting equipments and non-availability of assembling farming inputs such as fertilizers and insecticides. Lack of extension officers to educate farmers on new farming practices and inadequate logistics also led to its failure. Again, considering the local environment, the AP appeared "greenhorn" to the modern program and as a result, it was later changed to subsistence farming the AP's were conversant with. That notwithstanding, lessons were picked from the experiences of Akosombo modern agriculture program and fused into Kpong rehabilitation program. Although, the farming policy adopted under the Kpong resettlement scheme improved, it failed to meet its targets due to certain agronomic practices inadequacies like land clearing among others (Raschid-Sally et. al 2008).

\subsubsection{Procedural Delays in Compensation}

Undoubtedly, effective planning regimes for timely compensation payment to individuals in any resettlement project is a prerequisite for ensuring that AP get acclimatized to excesses associated with displacement. With respect to the Bui resettlement project, compensation estimation for the AP farm products was plagued with time overruns. That is to say, compensation emanating from the authorities came to the aid of the displaced individuals after two years (Mettle, 2011).

Also, providing AP with cash compensation packages can sometimes be dicey, detrimental and destructive. To buttress this point, with respect to the Akosombo resettlement project, AP were given the mandate to choose between minimum compensation and deciding to join a centralized resettlement communities. Interestingly, those who opted for cash compensation packages had to wait for a lengthy period of time (5 years) in order to have a feel of it (De wet 2006). Also, Kpong HEP suffered from the canker dubbed "delayed payment of compensation".

\subsubsection{Partiality}

The non-existence of Adam's Stacy's Equity Theory, Frederick Herzberg's 2 Factor Theory, Vroom's Expectancy Theory of Motivation, Abraham Maslow's Need Hierarchy, Human Relation Theory, Latham and Locke's Goal Setting Theory took its toll on the Akosombo resettlement project. Put simply, deficits relating to formal indicators for compensation determination influencing it in living up to its billing of success.

For instance, the valuation of houses and properties did not take cognizance of individuals existing structures and other edifices. The core housing units provided at the resettlement sites had the same dimensions irrespective of one's existing structures. This culminated into incessant disgruntling and hyperactive behaviours being exhibited by the AP towards the project kingpins just to mention a few (Adu-Gyamfi, 2015; Mettle, 2011; Ofori, 2008).

\subsubsection{Inadequate Compensation and Rehabilitation Assistance}

For over forty years that the Akosombo and Kpong resettlement scheme was implemented, there still exists a huge outstanding compensation of approximately seven hundred and fifty million Ghana cedis. This setback has conscentized countless number of host communities to retract or claim their lands creating myriads of animosity and restlessness among community folks (Kalitsi, 2008). Furthermore, Ghana News Agency (GNA) (2012) reported that farmers who were relocated as a result of the Bui dam felt disappointment with compensation package presented to them by the government. GNA (2012), opined the ordeal that were meted out to the farmers on the part of authorities by tricking and deceiving them through the destruction of economic crops with the hope of remitting them with mouth-watering goodies which never came into fruition (ERM, 2007; Mettle, 2011).

\subsubsection{Restrictive Implications of Livelihood Restoration Programs}

A research conducted by Volta Basin Project concluded that the destruction of economic or income generation activities within project affected areas led to a surge in prostitution, malfeasances, moral decadence, venereal diseases population dynamics, vis-a-vis massive rural-urban migration especially among the youth to nearby urban cities to improve their standard of living and the like (Partners Concept Papers, 2008). 


\subsection{Concept and Definition of Institutions}

Institutions increase the predictability of the decision-making situation by setting rules that govern the players, allowable actions and strategies, authorized results and linkages among decisions (Heywood, 2000). Institutions consist of formal rules and informal constraints. Helmke and Levitsky (2004) define their distinction as follows: Formal institutions are openly codified, in the sense that they are established and communicated through channels that are widely accepted as official. Contrariwise, informal institutions are socially shared rules, usually unwritten, that are created, communicated, and enforced outside of officially sanctioned channels'. Informal institutions are equally known but not laid down in writing and they tend to be more persistent than formal rules (North, 1997). The connection existing between formal and informal institutions is often closely aligned and informal institutions step in to prop up inefficient institutions. However, because they do not have a centre, which directs and coordinates their actions, changing informal institutions is a slow and lengthy process (Chang, 2007; Gielen, 2013).

\section{Research Methodology}

\subsection{Research Methodological Procedures Adopted}

As far as the approaches underpinning contemporary research is concerned, both quantitative and qualitative types cannot be overemphasized (Yates, 2004; Creswell, 2009). Quantitative research conducts a deductive approach to the relationship between theory and research which focus on testing of theory (Bryman \& Bell, 2011). Conversely, qualitative research dwells on the jargons rather than data quantification. It prefers conducting an inductive approach to the linkage existing between theory and research which pays homage to theories generation (Bell \& Bryman, 2011; Neuman, 2006). Both research approaches were adopted for the study. The adoption of each of the approaches in any research process are associated with constraints; hence, pitfalls embedded in any of them could cancel or neutralize the excesses of others. Put simply, quantitative method of research was employed because it combined practices and norm of the natural scientific model in positivism position and portrays a view of social reality as an external and objective reality (Bryman \& Bell, 2011). Furthermore, qualitative approach was considered in view of the fact that it provided a more realistic feel of the world that cannot be experienced in the numerical data as well as a holistic view of the phenomena under investigation (Matveev, 2007; Choy, 2014).

Descriptive method was opted for as the study's research strategy. A descriptive research intends to bring to the fore reality encompassing the magnitude and position of a scenario, in existence at the exact time the study was undertaken (Creswell, 2009). This research was cross-sectional as a result of time constraint. That is to say, this research was a survey of a distinct episode at a specified time period (Saunders, Lewis \& Thornhill, 2007). Accordingly, cross-sectional studies often employ the survey strategy, and they may be advocating to delineate the event of an episode.

Basically, the study relied on both primary and secondary data. The primary data were purely raw data and they were gathered directly from the inhabitants belonging to the 2 case study localities and were made up of figures, views, facts, opinions and personal experiences of the respondents in relation to the topic under scrutiny. They were generated by the application of the questionnaires, interviews and personal observation. Also, secondary information was gathered from published works including reports, journals, periodicals, internet sources and textbooks underpinning the researcher's chosen topic.

Research population in a statistical study is the entire group of individuals about which we want information whereas a sample connotes that part of the population from which we actually collect information used to draw conclusions about the whole (Moore, 2009; Sekaran \& Bougie, 2010). The targeted population for the study was 100 inhabitants emanating from the 2 chosen localities. Furthermore, a sample size of 50 was employed for the study comprising of folks within the case study localities with some peculiar characteristics in unison. The determination of the sample size was made possible through the utilization of Miller and Brewer Mathematical Equation (2003).

Sampling connotes the sorting out of a subset of individuals from within a statistical population in order to assess its absolute characteristics (Shahrokh \& Dougherty, 2014). Convenience sampling, also referred to as "haphazard sampling or accidental sampling" is a type of nonprobability or nonrandom sampling where members of the target population that meet certain practical criteria, such as easy accessibility, geographical proximity, availability at a given time, or the willingness to participate are included for the purpose of the study (Dornyei, 2007). Convenience sampling technique will be adopted for the study because of easy accessibility and proximity on the part of the researcher to most of the participants belonging to the case study localities used for the study. The main objective of convenience sampling is to collect information from participants who are easily 
accessible to the researcher like recruiting providers attending a staff meeting for study participation (Etikan, Musa \& Alkassim, 2016).

Questionnaires represent one of the popular data gathering technique employed in survey research. That is to say, the questionnaires utilized consist of both open and closed-ended feedbacks. Owing to the quantitative and qualitative nature of the data that was garnered, both techniques were relied upon in the analysis as postulated by Saunders, Lewis and Thornhill (2007). This strategy was opted for principally in the natural sciences and heavily reliant on information that can quantitatively be accounted for. Babbie (2010) opined that surveys, questionnaires, tests of personality, and standardized research instruments are undoubtedly hypothetical scenarios of apparatuses effectively utilized within the quantitative approach perspective. Conversely, Crotty (1998) posited that qualitative approach to research accentuates on systematic protocols and methods, where subjective parameters of the researcher are crafted into the fact findings and its concluding part. Interview of indigenes, folks among others who have been living in the chosen localities were conducted.

Responses were then be scripted and effectively made use of in order to map out formidable mechanisms to address the issues mentioned earlier as regards the specific objectives in consonance with the research questions. Five-Point Likert's scale was employed to develop the questionnaire in order to allow respondents to fish out the disparities in the responses vis-à-vis ensuring they had a myriad of options. The Likert scale was chosen because it has been successfully utilized in similar studies within the past few years as suggested by Haider \& Rasid (2002) as well as the publication of Raje, Dhobe \& Deshpande in 2002.

The study resorted to the Relative Importance Index (RII) method to investigate the key economic and social implications of resettlement schemes on displaced individuals as well as determine the critical factors affecting informal institutions in addressing resettlement issues in Ghana, using the inhabitants of the 2 afore-mentioned localities. The 5-Point Likert Scale ranging from 1(completely irrelevant) to 5 (Highly relevant) was applied and transformed to Relative Importance Indices (RII) for each of the factors as perceived by the respondent. RII scale is thus illustrated mathematically as below:

$$
R I I=\sum_{1}^{5} \frac{a_{i} n_{i}}{5 N}
$$

Where:

$\mathrm{a}=$ constant expressing the weight given to each factor by the respondents (ranging from 1 to 5).

$\mathrm{n}=$ frequency of each response

$5=$ a constant (i.e. 5 in this case), and

$\mathrm{N}=$ total number of respondents. The RII value had a range from 0 to 1 ( 0 not inclusive), the higher the value of RII, the more significant the key economic and social implications of resettlement schemes on displaced individuals via critical factors affecting informal institutions in addressing resettlement issues in Ghana. Furthermore, tools such as SPSS Version 22.0, etc. were employed for the data analysis.

Reliability refers to the extent to which a test or any measuring procedure yields the same results on repeated trials (Bell \& Bryman, 2011; Krippendorff, 2013). Validity on the other refers to the study's success at measuring or investigating what the researcher sets out to measure or investigate (internal validity) and the extent to which the research findings can be applied to new settings (external validity) (Creswell, 2009; Szafram, 2012). Measures were taken to ensure that the data collecting instruments employed were reliable and valid. The first measure involved the usage of multiple data collection instruments for the study. The findings from these different data collection tools were subsequently triangulated or compared in order to authenticate whether they provided similar findings.

Also, in conducting research, there is the need to normally ensure people are not harmed physically or emotionally and that is what ethical considerations are about. The researcher has a responsibility to ensure that research participants are protected (O'Leary, 2013). Apart from not doing harm, there is also the need to be truthful to the process (Coghlan \& Brannick, 2014). Curtis and Curtis (2011) observe that the most important aspect of an ethically appropriate research is voluntary informed consent. Potential respondents to the questionnaires were given assurance that the data collected were employed for the stated purpose and in no way identified the provider of such data. Also, respondents were informed to be objective since the researcher was under no circumstance looking for right or wrong answers. 


\subsection{Brief Profile of Ghana Dams Dialogue (GDD)}

The GDD was instituted in 2006, inspired by the processes and findings of the World Commission on Dams (WCD), with financial support from GTZ (Now GIZ) accepted to grant support to finance the second and again the third phase of the project (from 2007-2008 and 2009-2010). The founding principle of which was increasing interaction among key stakeholders, a critical issue for sustainable dam development (GDD, 2010a; International Water Management Institute (IWMI), 2011). The GDD was designed as a national dialogue process, following international and global examples of such processes. It is the first inclusive planning tool for the development of dams in the West African Region, providing multiple stakeholders with opportunities to hold discussions on irreconcilable differences and contributed to the development of equitable solutions. The GDD in keeping with the postulates of the WCD has equity; sustainability, efficiency; participatory; and accountability as the core values of future development of large dams (Nelson \& Selby, 2009; GDD, 2010a).

Since its establishment, GDD has functioned in three phases. The first phase of the project focused on the establishment of the dialogue; the second sought to strengthen the process; while the third phase aimed to consolidate its achievement. It has clarified the institutional setting and decision making processes and pathways for hydropower dams in Ghana. It has strived to reconcile national government issues with local level issues, as well as strengthened interactions between various sectors. It has also assisted in shaping the context of dams related issues by playing a key role in negotiations and resolving conflicts between stakeholder groups; knowledge- sharing and awareness creation (Nelson \& Selby, 2009) as mediators. The GDD also sought to learn from Kpong and Akosombo by involving the Dam Affected Communities (DACs) and Volta River Authority (VRA) (Koranteng, 2012).

\subsection{Brief Information on Kpong and VRA Resettlement Townships (KAVRTs)}

Situated in the Eastern Region of Ghana, the Kpong hydropower plant was built in 1982 and placed approximately $25 \mathrm{~km}$ downstream of the Akosombo dam. The project involved the construction of a dam, power house, spillway, and dykes, which created a head-pond covering an area of about $12 \mathrm{sq} . \mathrm{km}$ (Volta River Authority (VRA), 1996). The construction of Kpong Dam resulted in the resettlement of around 7,000 people. The hydropower plant has a capacity of $160 \mathrm{MW}$ in 4 units (VRA, 1996).

Established in 1961 under the Volta River Development Act (Act 46), the main task of VRA is to plan, execute and manage the development of the Volta River project. The key functions of VRA as stipulated under the Act included the identification of the hydropower potential of the Volta River and to generate electricity, above all for the development, construction and operation of a transmission system for the provision of electricity for industrial, commercial and domestic use (Agbemabiese, 2002; Girmay, 2006). The Authority is in charge of the Volta Lake as a source of fish and a mode of transportation of goods and passengers as well as for the management and well-being of the lake side settlements. Albeit, the main objective of VRA is to generate and supply electricity throughout Ghana (Agbemabiese \& Byrne, 2005).

Albeit operating since independence, the VRA is projected not to have delivered the promises of the provision of electricity to the Ghanaian population (Girmay, 2006). Subsequently, most of the people affected by the construction of the Kpong hydropower project were not connected to the national grid system until recently (Girmay, 2006). It would seem that the authority neglected the majority of the people affected in favour of the urban dwellers. On the encouraging side, however, the authority embarked on various programmes to manage the lake and the surrounding lake side villages (Agbemabiese, 2002). Some of these programmes include afforestation programme, weed controlling using both mechanical and manual clearing methods and to control schistosomiasis. There have also been dredging activities at Volta estuary and other kind of socio-economic impact mitigation measure such as Resettlement Trust Fund have been conducted by the Authority.

In the 1977's the Government of Ghana embarked on the construction of a second Hydro Electric Power at Kpong. The VRA was established as the implementing agencies. Six (6) resettlement towns were created for the relocation of the victims in addition to various compensation packages provided. Initially, the resettlement towns were arranged by VRA through governmental agencies such as the Social Welfare Department and the Ministry of Agriculture; each agency played a specific role. Management was coordinated by Town Managers where VRA employees worked closely with headmen who were settlers considered as group leaders.

A critical function of the VRA is to be responsible for safe guarding the health and socio - economic well-being of the inhabitants of the communities alongside the lake, and management of any incidental issues including sustainability of the environment. Over the years, there have been lapses in the management of these towns. In recent times, lots of complaints and representations had been made by the settlers, concerned groups, the media and major stakeholders. It appears the VRA had not been able to handle all the complex issues raised. Most 
recent studies have sought to examine the sustainability of hydroelectric dam projects in Ghana in terms of their environmental and social impacts. However studies that simultaneously examine the sustainability of development projects along environmental, economic, social and cultural dimensions are hard to come by (Kyei-Dompreh, 2012).

\section{Results and Discussion}

\subsection{Socio-Demographic Characteristics of Respondents}

This section of the study deals with the demographic information of respondents. It commences with the age distribution, marital status, stay duration, educational background, and key economic and social implications of resettlement schemes on displaced individuals in addition to the critical factors affecting informal institutions in addressing resettlement issues at the 2 chosen case study localities in Ghana. The study first asked respondents to indicate their gender. The responses were then analyzed using frequency and percentage table. The table 3 below depicts the socio-demographic characteristics of respondents at Kpong and VRA resettlement townships (KAVRTs). Amazingly, only 45 questionnaires returned to the researcher was used in the data analysis. The 45 questionnaires returned represented $90.0 \%$ rate of compliance or responsive for the study.

Table 3 accentuates on the socio-demographic characteristics of respondents at Kpong and VRA resettlement townships (KAVRTs)

Table 3. Socio-demographic characteristics of respondents

\begin{tabular}{|c|c|c|}
\hline Gender & Frequency & Percentage (\%) \\
\hline Male & 31.0 & 68.9 \\
\hline Female & 14.0 & 31.1 \\
\hline Total & 45.0 & 100.0 \\
\hline \multicolumn{3}{|l|}{ Age Ranges } \\
\hline $18-30$ & 12.0 & 26.7 \\
\hline $31-40$ & 7.0 & 15.6 \\
\hline $41-50$ & 18.0 & 40.0 \\
\hline $51-60$ & 5.0 & 11.1 \\
\hline Above 60 & 3.0 & 6.6 \\
\hline Total & 45.0 & 100.0 \\
\hline \multicolumn{3}{|l|}{ Marital Status } \\
\hline Single & 17.0 & 37.8 \\
\hline Married & 28.0 & 62.2 \\
\hline Total & 45.0 & 100.0 \\
\hline \multicolumn{3}{|l|}{ Stay Duration } \\
\hline $1-5$ & 17.0 & 37.8 \\
\hline $6-10$ & 23.0 & 51.1 \\
\hline $11-16$ & 4.0 & 8.9 \\
\hline Above 16 & 1.0 & 2.2 \\
\hline Total & 45.0 & 100.0 \\
\hline \multicolumn{3}{|l|}{ Educational Background } \\
\hline SSCE/WASSCE & 0.0 & 0.0 \\
\hline Diploma/HND & 14.0 & 31.1 \\
\hline First Degree & 23.0 & 51.1 \\
\hline Second Degree & 3.0 & 6.7 \\
\hline Other Professional Qualification & 5.0 & 11.1 \\
\hline Total & 45.0 & 100.0 \\
\hline
\end{tabular}

Source: Author's Field Data, 2017 
With reference to table 3 above, clearly shows that out of the 45 respondents at KAVRTs, 31.0 representing $68.9 \%$ were males and 14 which represented $31.1 \%$ were females. Secondly, $26.7 \%\left(2^{\text {nd }}\right)$ of the respondents' were between the ages of 18-30 years and subsequently had a frequency of 12.0, whereas 7.0 of them with a percentage score of $15.6 \%\left(3^{\text {rd }}\right)$ belonged to the $31-40$ years age bracket. Those within the age ranges of $41-50$ recorded the highest frequency $(18.0)$ with a percentage mark of $40.0 \%\left(1^{\text {st }}\right)$. However, those within the age brackets of 51-60 years as well as above the 60 years categories recorded minimal frequencies and percentage scores of both 5.0 and 3.0 in addition to $11.1 \%\left(4^{\text {th }}\right)$ and $6.6 \%\left(5^{\text {th }}\right)$ respectively.

Thirdly, it can deduced that the majority of the respondents are married couples with an optimal percentage mark of $62.2 \%$ and a corresponding frequency of 28.0 whereas the remaining 17.0 had a percentage score of $37.8 \%$. Marriage is a state of being responsible in life. The marital status which epitomizes the high rate of occurrence of married people belonging to KAVRTs workforce will invariably influence the responsibility levels of participants who took part in the survey. Furthermore, it can be inferred that those in the 1-5 year range had a percentage score of $37.8 \%\left(2^{\text {nd }}\right)$ with a corresponding frequency of 17.0 . This was closely accompanied by respondents who have been living at KAVRTs for the past 6 to 10 years. The category recorded the optimum frequency of 23.0 amongst the 4 other year brackets (service duration) and had a percentage score of $51.1 \%\left(1^{\mathrm{st}}\right)$. That notwithstanding, both $11-16$ years and above 16 years categories had percentage scores of $8.9 \%\left(3^{\text {rd }}\right)$ as well as $2.2 \%\left(4^{\text {th }}\right)$ with corresponding frequencies of 4.0 and 1.0 respectively.

Lastly, it can be inferred that $31.1 \%\left(2^{\text {nd }}\right)$ of the respondents were HND holders and had a frequency of 14.0 , $51.1 \%\left(1^{\text {st }}\right)$ were first degree holders with an accompanying frequency of 23.0 . More so, $6.7 \%\left(3^{\text {rd }}\right)$ represented second degree holders and had a frequency of 3.0 whereas those with other professional qualification had a percentage score of $11.7 \%\left(4^{\text {th }}\right)$ as well as an occurrence number of 5.0. That notwithstanding, SSCE/WASSCE category recorded a frequency as well as a percentage scoring of 0.0 and $0.0 \%$ respectively during the study.

Table 4 presents the views of respondents' on key economic and social implications of resettlement schemes on displaced individuals at KAVRTs, computed RII values and its subsequent rankings.

Table 4. Respondents' view on key economic and social implications (KESIs) of resettlement schemes (RSs) on displaced individuals (DIs) at KAVRTs, RII \& Ranking

\begin{tabular}{lcc}
\hline Key KESIs of RSs on DIs Parameters & RII Scoring & Ranking \\
\hline High morbidity/mortality rates (HMMR) & 0.859 & $1^{\text {st }}$ \\
Loss of economic power (status) (LEPS) & 0.818 & $2^{\text {nd }}$ \\
Compromising and destroying of farming systems (CDFS) & 0.722 & $3^{\text {rd }}$ \\
Livelihood deficits and marginalization (LDAM) & 0.671 & $4^{\text {th }}$ \\
Psychological and socio-cultural stress (PSCS) & 0.489 & $5^{\text {th }}$ \\
Disorganization and structure of local markets different from the previous & 0.378 & $6^{\text {th }}$ \\
patterns (DSLM) & & \\
\hline
\end{tabular}

Source: Author's Field Data, 2017

The table 4 above and figure 1 below indicates that respondents at KAVRTs opted for "High morbidity/mortality rates (HMMR)" as the most critical parameter in relation to the key economic and social implications (KESI) of displaced individuals in Ghana as it recorded an RII scoring of 0.859 and was ranked $1^{\text {st }}$. This was based on the 5-Point Likert scale's order of relevance which was later transformed into the Relative Importance Index (RII). The construct "HMMR" was edgily accompanied by "Loss of economic power (status) (LEPS)", "Compromising and destroying of farming systems (CDFS)", "Livelihood deficits and marginalization (LDAM)"categories with respective RII scorings of $0.818\left(2^{\text {nd }}\right), 0.722\left(3^{\text {rd }}\right)$ and $0.671\left(4^{\text {th }}\right)$. However, both "Psychological and socio-cultural stress (PSCS)" in addition to "Disorganization and structure of local markets different from the previous patterns (DSLM)" determinants recorded RII values of 0.489 and 0.378 and were subsequently ranked $5^{\text {th }}$ and $6^{\text {th }}$ respectively. 


\section{Bar Chart Depicting KESI of RSs on DIs, RII and Ranking}

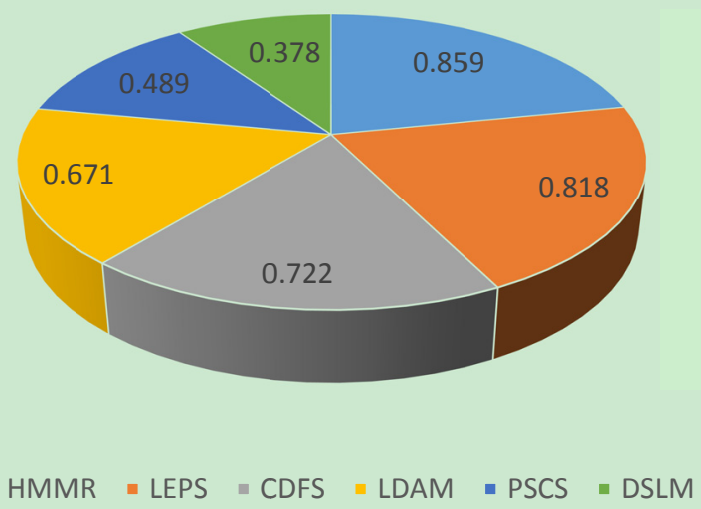

Figure 1. KESI of RSs on Dis

Source: Author's Field Data, 2017

Table 5 presents the views of respondents' on critical factors affecting informal institutions in addressing resettlement issues at KAVRTs, computed RII values and its subsequent rankings.

Table 5. Respondents' view on critical factors affecting informal institutions (IIs) in addressing resettlement issues (RIs) at KAVRTs, RII \& Ranking

\begin{tabular}{lcc}
\hline Critical Factors Affecting IIs in Addressing RIs & RII Scoring & Ranking \\
\hline Ineffective planning regimes (INEP) & 0.848 & $1^{\text {st }}$ \\
Restrictive implication of livelihood restoration programs (RILP) & 0.823 & $2^{\text {nd }}$ \\
Procedural delays associated with compensation (PDAC) & 0.699 & $3^{\text {rd }}$ \\
Lack of transparency in land allocation and farming techniques/partiality & 0.619 & $4^{\text {th }}$ \\
(LTAF) & & \\
Inadequate compensation and rehabilitation assistance (ICRA) & 0.558 & $5^{\text {th }}$ \\
Questionable housing policy (QUHA) & 0.426 & $6^{\text {th }}$ \\
\hline
\end{tabular}

Source: Author's Field Data, 2017

As per the critical factors affecting informal institutions (II) in addressing resettlement issues in Ghana, respondents at KAVRTs selected "Ineffective planning regimes (INEP)" as the most distinctive that cannot be overemphasized in that it had an RII score of 0.848 and was inadvertently rated $1^{\text {st }}$ comparatively (see table 5 above and figure 2 below). This was revealed by the 5-Point Likert model's order of significance. "INEP" determinant was closely followed by "Restrictive implications of livelihood restoration programs (RILP)", "Procedural delays associated with compensation (PDAC)" as well as "Lack of transparency in land allocation and farming techniques/partiality (LTAF)" attributes recorded RII scorings of $0.823,0.699$ and 0.619 and were subsequently ranked $2^{\text {nd }}, 3^{\text {rd }}$ and $4^{\text {th }}$ respectively. Furthermore, "Inadequate compensation and rehabilitation assistance" designated as "ICRA" had an RII value of $0.558\left(5^{\text {th }}\right)$ whereas "Questionable housing policy (QUHA)" recorded an RII scoring of 0.426 and was subsequently rated the least $\left(6^{\text {th }}\right)$ as compared to the 5 afore-mentioned constructs. 


\section{Critical Factors Affecting IIs in Addressing RIs, RII and Ranking}

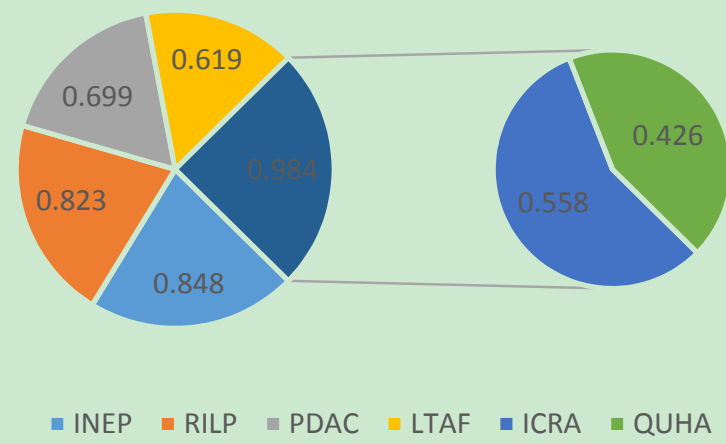

Figure 2. Critical Factors of Ris

Source: Author's Field Data, 2017

\subsection{Detailed Discussion of Results}

The 45 respondents' suggestions as depicted on the questionnaires conscentized the researcher to assign weighted values to each of the parameters identified as the key economic and social implications of resettlement schemes on individuals as well as the critical factors affecting the informal institutions in addressing resettlement issues at KAVRTs which, when strategically managed will inadvertently provide a long lasting remedy to the afore-mentioned issues relating resettlement in Ghana and beyond. In summary, with respect to the key economic and social implications of resettlement schemes on displaced individuals' factors at KAVRTs, 6pivotal categories were intimated by the respondents. These are (1) High morbidity/mortality rates (HMMR) (RII=0.859); (2) Loss of economic power (status) (LEPS) (RII=0.818); (3) Compromising and destroying of farming systems (CDFS) (RII=0.722); (4) Livelihood deficits and marginalization (LDAM) (RII=0.671); (5) Psychological and socio-cultural stress (PSCS) $(\mathrm{RII}=0.489)$ and lastly, (6) Disorganization and structure of local markets different from the previous patterns (DSLM) $(\mathrm{RII}=0.378)$.

Secondly, 6 critical factors affecting informal institutions in addressing resettlement issues at KAVRTs were ranked based on the order of relevance on the Five Point Likert scale which was later transformed into the Relative Importance Index (RII). According to the ranking relating to the RII, the 6 critical factors as revealed by the respondents' at KAVRTs are listed as: (1) Ineffective planning regimes (INEP) (RII=0.848); (2) Restrictive implication of livelihood restoration programs (RILP) (RII=0.823); (3) Procedural delays associated with compensation (PDAC) $(\mathrm{RII}=0.699)$; (4) Lack of transparency in land allocation and farming techniques/partiality (LTAF) (RII=0.619) and (5) Inadequate compensation and rehabilitation assistance (ICRA) (RII=0.558); and (6) Questionable housing policy (QUHA) (RII $=0.426$ ).

\subsection{Detailed Discussion of Results Relating to Research Question 1}

With respect to the research questions cited earlier, an in-depth analysis of the under-listed determinants is of immense relevance to the study:

\subsubsection{High Morbidity/Mortality Rates}

With respect to the key economic and social implications (KESI) of resettlement schemes (RSs) on displaced individuals (DIs) in Ghana, KAVRTs respondents opted for "High morbidity/mortality rates (HMMR)" as the most distinctive that cannot be overemphasized. "HMMR" recorded an RII scoring of 0.859 based on the 5-Point Likert scale's order of relevance and was subsequently rated $1^{\text {st }}$ comparatively (see table 4 and figure 1 afore-cited). It is worth noting that the respondents' findings agrees with the extensive research projects embarked upon by essayists like Mengistu (2005), Gebre (2009), vis-à-vis the publications of Wolde-Selassie (2009) and Cernea (2000).

\subsubsection{Loss of Economic Power}

In connection with the "KESI" of "RSs" on "DIs" in Ghana, respondents at KAVRTs selected "Loss of economic power (LEPS)" as the $2^{\text {nd }}$ most crucial determinant in view of that fact that it recorded an RII value of 0.818 
based on the 5-Point Likert model's order of importance (refer to table 4 and figure 1 cited earlier). Put simply, the submissions of Cernea et al. (2000b) appears to be in conformity with the respondent's findings during the study.

\subsubsection{Compromising and Destroying of Farming Systems}

"Compromising and destroying of farming systems" designated as "CDFS" for the purposes of this study was ranked $3^{\text {rd }}$ by the respondents at KAVRTs in consonance with the "KESI" of "RS" on "DIs" in Ghana. The construct in contention had an RII scoring of 0.722 as revealed by the 5-Point Likert scale's order of significance which was later upgraded into the Relative Importance Index (RII) (see table 4 and figure 1 cited earlier). Strictly speaking, the respondents' revelation is consistent with the comprehensive research work executed by Cernea (2000) entitled "Risks, Safeguards and Reconstruction: A Model for Population Displacement and Resettlement".

\subsubsection{Livelihood Deficits and Marginalization}

Respondents at KAVRTs opted for "Livelihood deficits and marginalization (LDAM)" as the $4^{\text {th }}$ most phenomenal as regards the key economic and social implications of resettlement schemes on displaced individuals in Ghana. The construct under scrutiny had an RII mark of 0.671 based on the 5-Point Likert scale's order of relevance in consonance with the results captured in table 4 and what figure 1 illustrates. Undisputedly, the research works embarked upon by the likes of Cernea and Mc Dowell (2000b) in addition to the postulate of Miine (2014) in his scholarly work captioned "Sustainability of Bui Resettlement Scheme in Ghana".

\subsubsection{Psychological and Socio-Cultural Stress}

Pertaining to the key economic and social implications of resettlement schemes on displaced individuals in Ghana, KAVRTs respondents chose "Psychological and socio-cultural stress" as the $5^{\text {th }}$ most pivotal in that recorded an RII scoring of 0.489 (refer to table 4 and figure 1 cited earlier). This was in consonance with the 5-Point Likert scale's pecking order which was later transformed into the Relative Importance Index (RII). Candidly speaking, the respondents' findings appears to be in conformity with the assertions of Mengistu (2005) in addition to Wolde-Selassie (2009) and Gebre (2009).

\subsubsection{Disorganization and Structure of Local Markets}

Lastly, "Disorganization and structure of local markets (DSLM)" was ranked $6^{\text {th }}$ by the respondents inhabiting the precincts of KAVRTs in connection with the "KESI" of "RSs" on "DIs" in Ghana. "DSLM" recorded an abysmal RII value of 0.378 based on the 5-Point Likert model's order of significance (see table 4 and figure 1 afore-cited). It is worthy of note that the respondents revelation shares some semblance with the arduous research projects executed by sustainability development affiliates likes of Miine (2014) in addition to the submissions of Ayanda (1988) and Cernea (2000).

\subsection{Detailed Discussion of Results Pertaining to Research Question 2}

The under-listed parameters depicts the detailed discussion of results in allusion to research question 2 :

\subsubsection{Ineffective Planning Regimes}

"Ineffective planning regimes (INEP)" was rated $1^{\text {st }}$ by the respondents at KAVRTs in connection with the critical factors affecting informal institutions in addressing resettlement issues in Ghana. "INEP" had an RII scoring of 0.848 as compared to the other 5 determinants based on the 5-Point Likert scale's order of significance (see table 5 and figure 2 cited earlier). Interestingly, the respondents revelation seems to be consistent with the submissions of Mettle (2011) as well as Yen (2003) in their research projects dubbed "Forced Resettlement in Ghana: The Dam and the Affected People. The Bui Hydroelectric Power Project in Ghana" and "Towards Sustainability of Vietnam's Large Dams: Resettlement in Hydropower Projects” respectively.

\subsubsection{Restrictive Implications of Livelihood Restoration Programs}

With particular reference to the critical factors affecting informal institutions in addressing resettlement issues in Ghana, KAVRTs respondents chose "Restrictive implications of livelihood restoration programs (RILP)" as the $2^{\text {nd }}$ most debilitating that cannot be underestimated. "RILP" had an RII value of 0.823 in tandem with the 5-Point Likert scale's order of relevance (refer to table 5 and figure 2 cited earlier). In the strict sense, the publication of Partners Concept Papers (2008) appears to be synonymous to the respondents' revelation during the study.

\subsubsection{Procedural Delays Associated with Compensation}

As per the critical factors affecting informal institutions in addressing resettlement issues in Ghana, respondents at KAVRTs opted for "Procedural delays associated with compensation" designated as "PDAC" in this paper as 
the $3^{\text {rd }}$ most crucial comparatively. The construct in contention had an RII scoring of 0.699 based on the 5-Point Likert model's pecking order (see table 5 and figure 2 afore-cited). Simply put, the respondents' discovery agrees with the postulates of Mettle (2011) and De Wet (2006) in his scholarly work captioned "Development-Induced Displacement: Problems, Policies and People".

\subsubsection{Lack of Transparency in Land Allocation/Farming Techniques and Partiality}

"Lack of transparency in land allocation/farming techniques and partiality (LTAF)" was rated $4^{\text {th }}$ by the respondents' at KAVRTs and recorded an RII score of 0.619 as revealed by the 5-Point Likert scale's relevance order (refer to table 5 and figure 2 cited earlier). This was connection with the critical factors affecting informal institutions in addressing resettlement issues in Ghana. Coincidentally, the respondent's fact findings conforms to the submissions of Adu-Gyamfi (2015), Mettle (2011), Ofori (2008) in additions to the extensive research projects embarked upon by Kalitsi (2008) and Raschid et al. (2008).

\subsubsection{Inadequate Compensation and Rehabilitation Assistance}

With regards to the critical factors affecting informal institutions in addressing resettlement issues in Ghana, respondents at KAVRTs selected the determinant in contention, designated as "ICRA" for the purposes of this paper as the $5^{\text {th }}$ most debilitating. "ICRA" recorded an RII scoring of 0.558 based on the 5-Point Likert scale's order of importance (see table 5 and figure 2 afore-cited). It is worthy of note that the respondents' findings tallies with the postulates of Kalitsi (2008), Mettle (2011), vis-à-vis what was captured in ERM (2007) and GNA (2012) publications.

\subsubsection{Questionable Housing Policy}

Respondents with the frontiers of KAVRTs opted for "Questionable housing policy (QUHA) as the $6^{\text {th }}$ most crucial in relation to the critical factors affecting informal institutions in addressing resettlement issues in Ghana. The perspective under scrutiny (QUHA) recorded an RII value of 0.426 in tandem with the 5-Point Likert model's relevance order and was the least preferred (refer to table 5 and figure 2 afore-cited). Simply put, the respondents' fact finding appears to be in synchrony with the assertion of De Wet (2006) including Gordon (2006) in his background paper for the "Multi-Stakeholder Consultation Process for Dams' Development in Ghana" captioned "Dams and development in Ghana" in relation to the "Volta Basin Research Project".

\subsection{Achievement of Objectives}

The research objectives have been duly achieved in the preceding chapters. The first objective which reads "To investigate the key economic and social implications of resettlement schemes on displaced individuals in Ghana?" has been thoroughly dealt with. In a nutshell, 6 key determinants were discovered by the respondents' within the frontiers of KAVRTs. It has thus been illustrated on table 4 and figure 1 cited earlier. The second objective was captioned "To determine the critical factors affecting informal institutions in addressing resettlement issues in Ghana?" has also been accomplished. This was achieved through the distribution of questionnaires to 45 inhabitants belonging to the precincts of KAVRTS. In the strict perspective, 6 critical factors affecting informal institutions in addressing resettlement issues at KAVRTs were realized by the researchers' based on the respondents' preferred options as it relates to the Relative Importance Index (RII) order of significance on the Five Point Likert scale (see table 5 and figure 2 spelt out earlier).

\section{Summary, Conclusions and Recommendations}

\subsection{Preview}

This segment wraps up the study, first, by abridging all the major themes dealt with spanning from chapters one through to chapter four. Then, base on the empirical findings captured in chapter four, in tandem with erstwhile literature, pivotal conclusions are arrived at. Getting to the tail end of the section, recommendations for managers and future researchers among others are proposed.

\subsection{Summary}

Contemporarily, sustainable development affiliates across the globe, spend considerable time planning their displacement, resettlement and rehabilitation strategic moves. For them, it is critical to be aware that the competitive strategy in the $21^{\text {st }}$ century appears very dynamic, intriguing and challenging that cannot be overemphasized. Undoubtedly, the inculcation of up-to-date strategic initiatives into any resettlement scheme will go a long way to impact positively on the living standards and socio-economic status of those displaced to a varying threshold.

As per the key economic and social implications of resettlement schemes on displaced individuals in Ghana, respondents at KAVRTs, 6 notable parameters were evident, namely: High morbidity/mortality rates (HMMR) 
$(\mathrm{RII}=0.859)$; Loss of economic power (LEPS) $(\mathrm{RII}=0.818)$; Compromising and destroying of farming systems (CDFS) (RII=0.722); Livelihood deficits and marginalization (LDAM) (RII=0.671); Psychological and socio-cultural stress (PSCS) (RII=0.489); including Disorganization and structure of local markets different from the previous patterns (DSLM) $(\mathrm{RII}=0.378)$.

More so, with particular reference to the critical factors affecting informal institutions in addressing resettlement issues within the precincts of KAVRTs, 6 parameters were opted for by the respondents based on the Five Point Likert Model relevance order relating to the Relative Importance Index values depicted in table 5 and figure 2 cited earlier, specifically: Ineffective planning regimes (INEP) (RII $=0.848$ ); Restrictive implications of livelihood restoration programs (RILP) $(\mathrm{RII}=0.823)$; Procedural delays associated with compensation (PDAC) $(\mathrm{RII}=0.699)$; Lack of transparency in land allocation/techniques and partiality (LTAF) $(\mathrm{RII}=0.619)$; Inadequate compensation and rehabilitation assistance (ICRA) (RII $=0.558)$ in addition to Questionable housing policy (QUHA) (RII=0.426).

\subsection{Conclusions}

In the concluding part of the study, it is so crystal clear that all the 45 respondents belonging to KAVRTs jurisdiction suggested "high morbidity/mortality rates" determinant as the most distinctive key economic and social implications of resettlement schemes on displaced individuals at KAVRTs, recording an RII value of 0.859 as revealed by the RII order of significance. This was closely accompanied by "Loss of economic power", "Compromising and destroying of farming systems", "Livelihood deficits and marginalization", "Psychological and socio-cultural stress" as well as "Disorganization and structure of local markets different from the previous patterns" with their respective RII scorings of $0.818 ; 0.722 ; 0.671 ; 0.489$ and 0.378 respectively.

Furthermore, with respect to critical factors affecting informal institutions in addressing resettlement issues at KAVRTs, 6 key parameters identified are categorically spelt out as below: "Ineffective communication regimes", "Ineffective planning regimes", "Restrictive implications of livelihood restoration programs", "Procedural delays associated with compensation", "Lack of transparency in land allocation/farming techniques/partiality", "Inadequate compensation and rehabilitation assistance" including "Questionable housing policy with accompanying RII values of $0.8480 .823 ; 0.699 ; 0.619 ; 0.558$ as well as 0.426 respectively.

Critically evaluating and analyzing the results with literature from past studies carried out by sustainable development contribute immensely in curtailing the encumbrances that incessantly continues to rear its ugly head as far as effective planning, implementation and management of resettlement schemes and plans in Ghana and the world in its entirety is concerned.

\subsection{Recommendations}

With reference to the critical factors affecting informal institutions in addressing resettlement issues at KAVRTs and the world at large, the under-listed strategic initiatives are of immense relevance to its management:

Promotion of interactions among stakeholders on compensation issues: It is imperative that GDD platform takes another positive leap to promote interactions among stakeholders on the issue of compensation payment. It is important for parties, especially the resettlement communities to understand the dynamics of compensation payment, especially land compensation and the processes involved. Time lines must be agreed upon by parties for payment of compensations and other benefits due affected communities.

Swift maturation of GDD policy levels: The policy level influences of GDD at the national level are still at a teething stage and will need to mature to be able to make the desired impact. It is therefore crucial for GDD to strengthen its financial and institutional base to be able to undertake programmes that will feed into national policy and legislations.

GDD strengthening of its engagement with relevant agencies: It is also recommended that GDD strengthens its engagement with the Lands Commission and other relevant Government Agencies to speed up issues on land title deeds as and when the need arises.

Effective participation: Effective participation by the affected communities and individuals in the resettlement process has been understood as one of the most potent means of managing incessant encumbrances associated with resettlement schemes across the globe. Absolute involvement and participation of AP has the propensity to protect the tax payer's money, and the lives of the AP from being destroyed and an opportunity to develop rural and indigenous populations since they are those mostly affected in dam construction.

Provision of social amenities: Authorities involved in resettlement projects should endeavour to assist the communities to build facilities (church, chief palace) that have not been provided in order to restore the 
community's religious and cultural activities;

Active NGO participation: NGOs must be involved in developing integral functions geared towards providing relevant assistance to vulnerable and marginalized members of the community; whose integration into the new settlement is likely to be slower and more painful than that of the rest of the community (inculcation of Abraham Maslow's Need Hierarchy, Max Weber's postulates, Total Quality Management (TQM) among others);

Promotion of shared cultural values: The preservation and translocation of the community's shared cultural values (strict adherence to Geert Hofstede's Cultural Dimension Theory) will assist the community through a period of hardships before economic wellbeing is restored. This should precede economic restoration;

Livelihood support programs (LSP): One tested and tried sustainability initiative that is supposed to ease the suffering of resettlers is the LSP. LSP provides a precautionary tool for those households for whom the disruption of economic and social networks may heighten the risk of vulnerability and increase the incidence of poverty, with all its negative consequences. This should be executed with the assistance of an NGO supervised by the LSP Committee, comprising of traditional authority, organizational representative in charge of the implementation of the Resettlement Action Plan, Resettlement Coordinator, via Livelihoods NGO official. The LSP targets comprises of farming, fishing, trading, grazing, hunting and collection of forest products and the like.

Continuous monitoring and evaluation: There should be continuous monitoring and evaluation mechanism which will invariably provide the platform to assess the overall success of the resettlement and the effectiveness of the various processes and measures.

Individual's stability: The stability of the people in the community heavily depends on the stableness of means for living and production. Strategic Housing unit planning should be suitable to both physical conditions and traditional customs of living, cultivation, and culture. Models of houses should be selected by people (or rather designed with the participation of the people) to protect identity of ethnologies in term of material culture.

Strict adherence to a single management body: Lastly, a single management body from high to local level is an indispensable attribute to live up to the billing of high success rate. Undoubtedly, this strategy is one sure bet of effectively managing investment sources, vis-à-vis bearing the absolute responsibility of a project's superior quality or defect reduction to the six sigma level. This body could also receptive to the response emanating from the local folks and strategically and tactfully address practical intriguing enigmas (issues).

\subsection{Limitations of the Study}

With respect to the issues identified during the study, the under-listed constraints are of immense relevance to the study:

- Inconsistency in some of the feedbacks received from respondents;

- Waiting for too long (time constraints) in order to have access to some of the filled questionnaires within the precincts of KAVRTs;

- Unwillingness on the part of those who filled the questionnaires to hit the nail rightly on the head (precision) at KAVRTs.

- Language constraints (translation into the local dialects also took its toll on the result gathered for the analysis).

\subsection{Suggested Areas for Further Research}

Replicated studies could be effectuated with respect to other geographical resettlement zones within the country using the same or diversified methodological approaches which may, however, be subject or the bone of contention for further development and improvement.

\section{References}

Abdel Ati, H. A. (1992). The damming of the River Atbara and its downstream impact. In Darkoh, M.B.K. (Ed.), African river basins and dryland crises (pp. 21-43). Uppsala, Sweden.

Acreman, M., Farquharson, F. A. K., McCartney, M. P., Sullivan, C., Campbell, K., Hodgson, N. ... Barbier, E. B. (2000). Managed flood releases from reservoirs: issues and guidance. Report to DFID and the World Commission on Dams Centre for Ecology and Hydrology, Wallingford, UK.

Adams, W. M., \& Aminu-Kano, M. (2013). The Hedejia-Nguru Wetlands. Environment, economics and sustainable development of a Sahelian Floodplain. IUCN; Gland, Switzerland. 
Adu-Gyamfi, A. (2012). An overview of compulsory land acquisition in Ghana: Examining its applicability and effects. Journal of Environmental Management and Sustainable Development. USA.

Adu-Gyamfi, A. (2015). Involuntary resettlement in Ghana: Implementation, planning and management of social impacts in hydropower projects. Developing Country Studies, 5(4), 44-57.

Agbemabiese, L. (2002). Toward a political economy of Sustainable energy in Ghana: A paradigm analysis of energy-development relations from the $11^{\text {th }}$ century to the present. Doctoral dissertation, University of Delaware, Newark.

Agbemabiese, L., \& Byrne, J. (2005). Commodification of Ghana's Volta River: An example of Ellul's autonomy of technique. Bulletin of Science, Technology \& Society, 25(1), 17-25. https://doi.org/10.1177/0270467604273821

Asante-Manteaw, A. (2011). An appraisal of the land access processes in the mining industry of Ghana: The case of Newmont Ghana Gold Limited (NGGL), Ahafo Mine. A thesis submitted to Kwame Nkrumah University of Science And Technology (KNUST), Ghana for Commonwealth Executive Master of Business Administration (CEMBA).

Asian Development Bank (ADB). (2010). Involuntary resettlement. Retrieved from www.adb.org/documents/policy-involuntary-resettlement

Ayanda, J. O. (1998). Economics of traditional fish preservation and storage techniques in Jebba Lake Basin. NIFFR Annual Report, (New Bussa: NIFFR).

Babbie, E. (2010). The practice of social research (12th ed.). Cengage Learning, Mason.

Barbier, E. B., Adams, W. M., \& Kimmage, K. (1993). An economic valuation of wetland benefits. In: Hollis, G.E.

Bartolome, L. P., De Wet, C., Mander, H., \& Nagraj, V. K. (2000). Displacement, resettlement, rehabilitation, reparation, and development. World Commission on Dams (WCD) Thematic Review Social Issues, 1(3), $1-77$.

Bell, E., \& Bryman, A. (2011). Business research methods (3rd ed.). Oxford, UK: Oxford University Press.

Brightmer. M. I. (1983). Man-made lakes and human health in Africa, with special reference to Lake Kainji, Nigeria. Unpublished M.Sc. Dissertation, Department of Geography, University of London, 1-73.

Cernea, M. (2004). Impoverishment risk, risk management, and reconstruction: A model of population displacement and resettlement. Paper presented at the UN Symposium on Hydropower and Sustainable Development in support of, and as background to, the Keynote Paper prepared by the same author in the set of sessions of the Symposium devoted to the Social Aspects of Hydropower Development. Beijing, October 27-29 2004. George Washington University, Washington, D.C., USA. Retrieved from http://www.un.org/esa/sustdev/sdissues/energy/op/hydro_cernea_population_resettlement_backgroundpaper .pdf

Cernea, M. M. (1996). Understanding and preventing impoverishment from displacement: Reflections on the state of knowledge. In C. McDowell (Ed.), Understanding impoverishment: the consequences of development induced displacement. Oxford: Berghahn Books.

Cernea, M. M. (1997a). Hydropower dams and social impacts: A sociological perspective. Social Development Papers, 16.

Cernea, M. M. (1997b). African involuntary population Resettlement in a global context. Environment Department Papers. Social assessment series. Washington DC: World Bank.

Cernea, M. M. (1999). The economics of involuntary resettlement: questions and challenges. Washington, D.C. The World Bank. https://doi.org/10.1596/0-8213-3798-X

Cernea, M. M. (2000). Risks, safeguards and reconstruction: A model for population displacement and resettlement. In M. M. Cernea, \& C. M. Dowell (Eds.), Risks and reconstruction: Experiences of resettlers and refugees (pp. 11-55). Washington D. C. The World Bank. https://doi.org/10.1596/0-8213-4444-7

Cernea, M. M. (2008). Plenary session speech presented to the Society for Applied Anthropology Conference. Memphis, Tennessee, March 26, 2008.

Cernea, M. M., \& McDowell, C. (2000). Risks and reconstruction: Experiences of resettlers and Refugees. Washington: The World Bank. https://doi.org/10.1596/0-8213-4444-7 
Chang, H.-J. (2007). Institutional change and economic development. Anthem Press.

Choy, L. T. (2014). The strengths and weaknesses of research methodology: Comparison and complimentary between qualitative and quantitative approaches. IOSR Journal of Humanities and Social Science (IOSR-JHSS), 19(4), 99-104.

Coghlan, D., \& Brannick, T. (2014). Doing action research in your own organization (4th ed.). Los Angeles, CA: Sage.

Creswell, J.W. (2009). Research design: Qualitative, quantitative and mixed methods approaches (3rd ed.). London: Sage Publications, Incorporated.

Crotty, M. J. (1998). The foundations of social research: Meaning and perspective in the research process. Sidney: Allen Unwin.

Curtis, B., \& Curtis, C. (2011). Social research: A practical introduction. Los Angeles, CA: Sage. https://doi.org/10.4135/9781526435415

De Wet, C. (2006). Development-induced displacement: Problems, policies and people. Berghahn books.

Dörnyei, Z. (2007). Research methods in applied linguistics. New York: Oxford University Press.

Duvail, S., \& Hamerlynck, O. (2003). Mitigation of negative ecological and socio-economic impacts of the Diama dam on the Senegal River Delta wetland (Mauritania), using a model based decision support system. Hydrology and Earth System Sciences, 7(1), 133-146. https://doi.org/10.5194/hess-7-133-2003

Environmental Resource Management (ERM). (2007). Resettlement planning framework for the Bui hydropower project. Prepared by the Environmental Resources Management, in association with SGS Environment. Approved and signed by Eamonn Barrett for and on behalf of Environmental Resources Management.

Etikan, I., Musa, S. A., \& Alkassim, R. S. (2016). Comparison of convenience sampling and Purposive sampling. American Journal of Theoretical and Applied Statistics, 5(1), 1-4. https://doi.org/10.11648/j.ajtas.20160501.11

Fernandes, W., Nafisa, G. D., Arundhuti, R. C., \& Mohammed, A. (2001). Development-induced displacement, deprivation and rehabilitation in Andhra Pradesh, 1951-1995: A quantitative and quantitative study of its extent and nature. New Delhi: Indian Social Institute and Guwahati: North Eastern Social Research Centre.

GDD. (2010). Ghana dams dialogue newsletter. Issue 6, Accra.

Gebre, Y. (2009). Why did resettlement fail? Lesson from Metekel. In A. Pankhurst, \& F. Pigeut (Eds.), Moving people in Ethiopia, development displacement and the state. Eastern Africa Series, Addis Ababa.

Ghana News Agency (GNA). (2012). Farmers affected by Bui dam construction not happy with compensation. Retrieved March 1, 2013, from http://www.spyghana.com/farmers-affected-by-bui-dam-construction-not-happywith-compensation/

Gielen, P. (2013). Institutional attitudes: Instituting art in a flat world. Valiz: Amsterdam.

Girmay, Y. (2006). Assessing the environmental impacts of a hydropower project: The case of Akosombo/Kpong dams in Ghana. MSc Thesis, Royal Institute of Technology, Stockholm, Sweden.

Gordon, C. (2006). Dams and development in Ghana. Background Paper for the multi-stakeholder consultation process for dams' development in Ghana, Volta Basin Research Project, Ghana. Retrieved from http://new.unep.org/dams/files/Country\%20Dialogues/BackgroundStudyGhana.pdf

Gyau-Boakye, P. (2001). Environmental impacts of the Akosombo Dam and effects of climate change on the lake levels. Environment, Development and Sustainability, 3, 17-29. https://doi.org/10.1023/A:1011402116047

Haider, W., \& Rasid, H. (2002). Eliciting public preferences for municipal supply options. Environmental Impact Assessment Review, 22, 337-360. https://doi.org/10.1016/S0195-9255(02)00017-3

Helmke, G., \& Levitsky, S. (2004). Informal institutions and comparative politics: A research agenda. Perspect. Polit. 4, 725-740. https://doi.org/10.1017/S1537592704040472

Heywood A. (2000). Key concepts in politics. Palgrave Macmillan, Basingstoke, England.

Hordofa, L.T. (2003). Development (development through forced displacement) induced impoverishment: The case of Karrayu Oromo of Upper Awash Valley, Oromia, Ethiopia. Paper presented at the International Conference on Researching Internal Displacement: State of the Art. 7 - 8 February in Trondheim, Norway. 
IMWI. (2011). Facilitating dialogue for sustainable development. Issue 12, 1-2.

International Rivers. (2011). Development-induced displacement: Three Gorges dam. Training on the protection of IDPs. Retrieved from http://www.internationalrivers.org/china/three-gorges-dam

Kalin, W. (2000). Guiding principles on internal displacement, studies in transitional policy. The American Society of International Law, (32).

Kassahun, B. (2000). Returnees, resettlement and power relations: The making of a political community in Humera, Ethiopia. Ph.D. dissertation, Free University of Amsterdam, Faculty of Socio-Cultural Sciences, April.

Koranteng, R. T. B. (2012). Monitoring of natural resource governance: assessment of changes in policy and practice as a result of the multi-stakeholder Ghana dams dialogue (GDD). Report, 1-40.

Krippendorff, K. (2013). Content analysis: An introduction to its methodology (3rd ed.). Los Angeles, CA: Sage.

Kyei-Dompreh, F. (2012). Management of VRA resettlement towns: Case study of West Kpong resettlement town. CEMBA Thesis, KNUST, 1-92.

Larbi, W. O. (2008). Compulsory land acquisition and compensation in Ghana: Searching for alternative policies and strategies, FIG/FAO/CNG International Seminar on State and Public Sector Land Management, Verona, Italy, September 9-10, 2008. Retrieved September 10, 2012, from http://www.fig.net/commission7/verona_fao_2008/papers/09_sept/4_1_larbi.pdf

Lund, R. (2009). Development-induced displacement and resettlement: An introduction to the concept, magnitude, impacts and dilemmas (Online lecture). Trondheim, Norway: Norwegian University of Science and Technology.

Magembe-Mushi, D. L., \& Lupala, J. M. (2015). Resettling displaced residents from regularized informal settlements in Dar-es-Salaam, Tanzania: Challenges faced by house owners. Ardhi University, Dar es Salaam, Tanzania. Scientific Research Publishing Inc., 1-11.

Matveev, A. (2007). The advantages of employing quantitative and qualitative methods in intercultural research: Practical implications from the study of the perceptions of intercultural communication competence by American and Russian managers, 1-7.

Mc Donald, B., Webber, M., \& Yuefang, D. (2008). Involuntary resettlement as an opportunity for development: The case of urban resettlers of the three gorges project. China. J. Refugee Stud., 1(21), 82-102. https://doi.org/10.1093/jrs/fem052

McCartney, M. P., Alemayehu, T., Shiferaw, A., \& Awulachew, S. B. (2010). Evaluation of current and future water resources development in the Lake Tana Basin, Ethiopia. Colombo, Sri Lanka: International Water Management Institute. Colombo, Sri Lanka: International Water Management Institute. IWMI Research Report 134.

McCartney, M. P., Awulachew, S., Seleshi, Y., Prasad, K., King, J., \& Tarekegn, D. (2005). Decision support systems for dam planning and operation in Africa - 2005. Project leaders meeting on decision support systems for dam planning and operation in Africa, Entebbe, Uganda. $28^{\text {th }}$ November 01 December 2005. Colombo, Sri Lanka: CGIAR Challenge Program on Water and Food.

Mengistu, W. (2005). Effects of resettlement schemes on the biophysical and human environments: The Case of Gambela Region, Ethiopia. Boca Raton: Universal Publishers.

Mettle, M. (2011). Forced resettlement in Ghana: The dam and the affected people. The Bui Hydroelectric Power Project in Ghana, Thesis for Award of Master of Philosophy in Development Studies Specialising in Geography, Norwegian University of Science and Technology (NTNU).

Miine, L. K. (2014). Sustainability of Bui resettlement scheme in Ghana. Master's Thesis. Development Policy and Planning, College of Architecture and Planning, 1-128.

Miller, R. L., \& Brewer, J. D. (Eds.). (2003). The A-Z of social research. London: Sage. https://doi.org/10.4135/9780857020024

Moore, D. S. (2009). The practice of business statistics: Using data for decisions (2nd ed.). New York: W.H. Freeman and Co.

Mouafo, D., Fotsing, E., Sighomnou, D., \& Sigha, L. (2002). Dam, environment and regional development: case study of the Logone Floodplain in Northern Cameroon. Water Resources Development, 18, 209-219. 
https://doi.org/10.1080/07900620220121765

Mulugeta, M., \& Woldesemait, B. (2011). The impact of resettlement schemes on land use land cover changes in Ethiopia. A case study from Nonno resettlement sites, Central Ethiopia. Journal of Sustainable Development in Africa, 13, 269-293.

Munshifwa, K. E. (2007). Migration, and resettlement and conflict at Kambmb resettlement scheme on the Copperbelt: Implications for policy. Paper prepared for presentation at the Southern Africa-Nordic Centre (SANORD) Conference planned for the University of Western Cape on 5-8 December 2007.

Nelson, N. B., \& Selby, H. (2009). Success and challenges of the Akosombo and Kpong resettlement schemes: Lessons learned for the Bui scheme.

Neuman, W. L. (2006). Social research methods: Qualitative and quantitative approaches (6th ed.). Pearson International Edition, USA.

North, D. (1997). The contribution of the new institutional economics to an understanding of the transition problem. WIDER Annual Lecture 1. UNU World Institute for Development Economics Research, Helsinki, $1-19$.

O'Leary, N. (2013). The essential guide to doing your research project (2nd ed.). Los Angeles, CA: Sage.

Ofori, D. B. (2008). Strategies for community participation in dam development. Submitted at International Water Management Institute (IWMI), West African Regional Office, Accra.

Olawepo, R. A. (1997). Resettlement and rural development: The dynamics of rural change in the resettled villages of Jebba Lake Basin. PhD Thesis, Department of Geography, University of Ilorin, Nigeria.

Oliver-Smith, A. (2002). Displacement, resistance and the critique of development: From the grass-roots to the global. RSC Working Paper No. 9. International Development Centre University of Oxford.

Oucho, J., \& Rodgers, G. (2005). Overview of internal displacement in the SADC region. Paper presented at the regional seminar on internal displacement in the Southern African Development Community (SADC) region Gaborone, Botswana. 24-26 August 2005 cosponsored by: The Office of the United Nations High Commissioner for Refugees, The Representative of the United Nations Secretary- General on the Human Rights of Internally Displaced Persons and The Brookings Institution - University of Bern.

Pankhurst, A., \& Piguet, F. (2009). Moving people in Ethiopia: Development, displacement and the state. Rochester, NY. James Currey.

Partners Concept Paper. (2008). Re-optimization of operations of Akosombo and Kpong Dams on the Volta River in Ghana to restore downstream livelihoods and ecosystems. April $28^{\text {th }} 2008$.

Phonepraseuth, V. (2012). From a resettlement to sustainable livelihood development: The Potential of resettlement and livelihood restoration arrangement to achieve livelihood sustainability, a case study of resettled communities on the Nakai Plateau Nam Theum 2 Hydropower project in Lao PDR. Published M Phil. (Development Studies) Massey University Palmerston, North New Zealand.

Raje, D. V., Dhobe, P. S., \& Deshpande, A. W. (2002). Consumer's willingness to pay more for municipal supplied water: A case study. Ecological Economic, 42, 391-400. https://doi.org/10.1016/S0921-8009(02)00054-X

Raschid-Sally, L., Akoto-Danso, E. K., Kalitsi, E. A. K., Ofori B. D., \& Koranteng, R. T. (2008). The resettlement experience of Ghana analyzed via case studies of the Akosombo and Kpong dams. Paper presented at the $9^{\text {th }}$ Annual Symposium on Poverty Research in Sri Lanka exploring experiences of resettlement.

Robinson, C. W. (2003). Risks and rights: The causes, consequences, and challenges of development-induced displacement. Occasional Paper. The Brookings Institution - SAIS Project on Internal Displacement.

Rural Development Institute (RDI) of ADB. (2007). Compensation and valuation in resettlement: Cambodia, People's Republic of China, and India. Printed in Philippines.

Saunders, M., Lewis, P., \& Thornhill, A. (2007). Research methods for business students (4th ed.). Pearson Education Limited. Edinburgh Gate, England, 586.

Scudder, T. (2005). The future of large dams, dealing with social, environmental, institutional and political costs. Earthscan publication, UK.

Sekaran, U., \& Bougie, R. (2010). Research methods for business: A skill building approach (5th ed.). Hoboken, N.J./Chichester: John Wiley and Sons. Div. 
Shahrokh, E. M., \& Dougherty, E. (2014). Effect of separate sampling on classification accuracy. Bioinformatics, 30(2), 242-250. https://doi.org/10.1093/bioinformatics/btt662

Sutcliffe, C. (2009). Interviews with people to be affected by Bui dam: A field report. Retrieved from http://www.internationalrivers.org/files/Bui\%20Field\%20Report.pdf

Szafram, R. (2012). Answering questions with statistics. Los Angeles, CA: Sage.

UN-HABITAT. (2008). State of the world's cities 2008/2009: Harmonious cities. Earthscan: London, 24, 1-13.

UNHCR. (2011). Resettlement handbook. Switzerland United Nations High Commissioner for Refugees.

United Nations High Commission for Refugees (UNHCR). (2004). Progress report on resettlement. Retrieved May 13, 2014, from http//wwwUnhcr.Org/40c706964.html

Wolde-Selassie, A. (2009). Social impact of resettlement in the Beles Valley. In A. Pankhurst \& F. Pigeut (Eds.), Moving people in Ethiopia, development displacement and the state. Eastern Africa Series: Addis Ababa.

World Commission on Dams (WCD). (2000). Dams and development. London: Earthscan Publications.

Woube, M. (2005). Effect of resettlement schemes on the biophysical and human environments: The Gambala Region, Ethiopia. Florida: Universal Publishers.

Yates, J. S. (2004). Doing social science research. London. Sage Publications.

Yen, C. T. T. (2003). Towards sustainability of Vietnam's large dams: Resettlement in hydropower projects. Department of Infrastructure, Department of Infrastructure, Royal Institute of Technology, Sweden.

Yen, C. T. T. (2003). Towards sustainability of Vietnam's large dams: Resettlement in hydropower projects. Department of Infrastructure, Department of Infrastructure, Royal Institute of Technology, Sweden.

Zaman, M. Q. (2010). Land acquisition and compensation in involuntary resettlement. Land and Resources, 14(4).

\section{Copyrights}

Copyright for this article is retained by the author(s), with first publication rights granted to the journal.

This is an open-access article distributed under the terms and conditions of the Creative Commons Attribution license (http://creativecommons.org/licenses/by/4.0/). 